\title{
Characterization of Sugar Industry Waste (Filter Cake) and Agro-waste Crop Residue as Potential Source of Livestock Feed Raw Materials
}

Adugna Ayu Abera ( $\sim$ ayu328054@gmail.com )

Arba Minch University https://orcid.org/0000-0001-8779-8550

Ramesh D Duraisamy

Arba Minch University

Tolera Badessa Seda

Arba Minch University

Research article

Keywords: Livestock feed, Filter cake, Croup residue, Utilization, potential

Posted Date: August 27th, 2020

DOI: https://doi.org/10.21203/rs.3.rs-36941/v1

License: (c) (i) This work is licensed under a Creative Commons Attribution 4.0 International License.

Read Full License 
Title: Characterization of Sugar Industry Waste (Filter Cake) and Agro-waste Crop Residue as Potential Source of Livestock Feed Raw Materials

By: Adugna Abera Ayu*, Ramesh Duraisamy and Tolera Seda Badessa

• adugnaabera2002@gmail.com

$>$ adugna.abera@amu.edu.et

•drrameshmcas@gmail.com

$>$ ramesh.duraisamy@amu.edu.et

• toleraseda@yahoo.com

$>$ tolera.seda@amu.edu.et 


\begin{abstract}
The potential searching on sources of livestock feed material is the major constrain in the sustainability of livestock sector for the future. The utilization of cereal crop residues (CCRs) is limited because they contain a large proportion of lignocellulosic compounds and little nitrogen. The filter cake is a poorly studied potential as forage for ruminants. In addition, they show higher fiber content. The analysis on characterization of filter cake, Teff straw, barley straw and corn cob were carried out through proximate analysis such as moisture content (MC), dry mater $(D M)$, organic dry matter $(O D M)$, ash content $(A C)$, crude protein $(C P)$, crude fiber $(C F)$, Elemental analyzer, $U V$ Visible spectroscopy and Fourier transform infrared spectroscopy were used for analyzing the elemental profiles and functional feed constitutions. The proximate analysis of raw material feed stocks (in \%) contains in the range of $D M(96.54 \pm 0.7-89.5 \pm 0.5), O D M(98.33 \pm 0.3-79.4 \pm 0.4), M C(3.45 \pm 0.7-10.5 \pm 0.5), C P(2.32 \pm 0.58-12.92 \pm 0.36), C F$

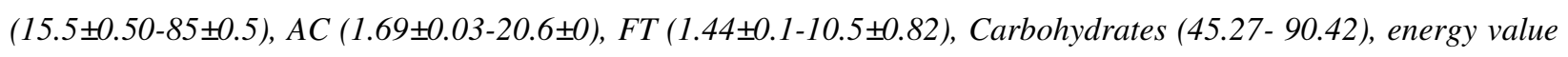
(327.26- 386.56 kcal.) and Sucrose of $(3.85 \pm 0.83)$. And its elemental compositions can be addressed by their mineral matter contain up 1.69 $\pm 0.03-20.6 \pm 0 \%$. The moisture content and dry matter contents may vary depends on factors such as cultivator of crops and cane, location, climate, dry length, soil pest diseases, cultivation practices, the harvesting practice and the processing of cans and crops. Large quantities of fibrous crop residues are already used as animal feed in many areas across these countries. There are too many areas in developing countries where ruminant livestock starves due to lack of feed. So this study shows that the direction of searching and compensating the availability of such important croup residues and the sugar industry by product (filter cake) as the raw sources of livestock feeds.
\end{abstract}

Key words: Livestock feed, Filter cake, Croup residue, Utilization, potential 


\section{Introduction}

Sugar is mainly produced from sugar cane and sugar beet. On the processing of sugar, during the clarification of cane juice or beet juice, most of the non-sugar components are flocculate or precipitated by the action of milk of lime and carbon dioxide or sulfur dioxide. The precipitate is allowed to settle in a clarifier and the settled sludge is filtered by using a rotary vacuum filter. The solid waste generated as a byproduct on clarification of juice before its concentration and crystallization, which is called filter cake (also known as press mud) (Peymaneh et al. 2014). The solid byproducts from the sugar processing are being widely known as bagasse and press mud (Khan et al. 2018). The issue of Bio-energy (seeking a source of renewable energy), is a serious issue in all over the world and has passed a big hurry to increase sugar and ethanol yield, which in turn has increased the size of fields planted with sugar cane; thereby contributing to the production of more waste from sugar milling, treatment and ethanol through distillation. Within this new scenario, it creates the need for more detailed nutritional information on the use of such byproduct in ruminant feed (Rouf et al, 2010). It is also reported that SPR is a potential source of protein, high amount of sugar and other nutrients, including major minerals such as $\mathrm{Ca}, \mathrm{P}, \mathrm{K}, \mathrm{Mg}$, and $\mathrm{S}$ as well as trace elements

$\mathrm{Cu}, \mathrm{Fe}, \mathrm{Zn}$, and Mn. Press-mud was used for the formulation of livestock feed because of its higher CP content and more soluble calcium/magnesium, which is an important constituent of animal feed (Suresh et al. 2006). However, the composition of the sugar cane press residue would vary from place to place, the extent of factory mechanization, sugarcane growing belt, etc. The filter cake is a poorly studied potential as forage for ruminants. In addition, they show higher fiber content this is because bagasse is added to the rotary vacuum process and its purpose is to act as a porous layer on the surface of the filter (Said and Dzowela, 1989). Among the forgue

The utilization of cereal crop residues (CCRs) is limited because they contain a large proportion of lignocellulose compounds and little nitrogen.

Teff straw, the crop residue of the grain harvest is a major livestock fodder in Ethiopia. Teff straw, called ch'ed is the main by-product of the teff grain harvest and a basal component of livestock diets in this country. Its yield is about 3 times that of the grain, at about 5-7 t DM/ha (Seyfu, 1997).

According to (Grove et al, 2003) studies the proximate composition of barley straw as, Dry matter (DM), are 93.1 $\%$, Crude protein (CP) $4.4 \%$, Neutral detergent fiber (NDF) $77.3 \%$, Non-fiber carbohydrate (NFC) $11.5 \%$. Nutritionists may recommend including some straw in the lactating cow total mixed rations for rumination, desire to increase rumen fill and (or) or slow the rate of passage of digest from the rumen when only finely chopped and (or) 
very highly digestible forages are available on the farm, and the need to extend farm forage inventories (Shaver and Hoffman, 2010).

Corn cob is the central core of an ear of maize (Zea mays). It is the part of the ear on which the kernels grow. When harvesting the corn, the corn cob may be collected as part of the ear or instead may be left as a waste in the field (Abubakar et al, 2016). In view of the need for waste management and recent awareness of conversion of wastes to wealth, this study was conducted to determine the proximate composition of both sugar cane industry (filter cake) and crop residues (teff and barley straw and corn cob). And mineral analysis of filter cakes to show as their possible potential sources of livestock feed raw material. And also filter cake is usually dumped as garbage. Some sugar industries make use of it by converting it into compost. But this compost, along with its advantages, has some disadvantages too. It increases the wax content in the soil. The increase in wax reduces the porosity of the soil causing clogging. Thus, utilizing of filter cake in the production of animal feedstock is a safer option than composting (Sahu et al, 2016 and Peymaneh et al, 2014). The current study showed that the potential uses of filter cake micro and macro nutrient composition and croup residues (forge) as the raw sources in the processing of livestock feeds because of their accessibility and low cost. 


\section{MATERIALS and METHODS}

\section{The aim of this research}

The main objectives of this study is assessing and characterization of livestock's feed material from agro-wastes of teff \& barley straws and corncob with that of sugar industrial byproduct filter cake.

\section{Experimental Design}

The study was divided into the following areas;

$\square$ Feedstock material collection, identification and proximate analysis.

$\square$ Qualitative (FTIR) and quantitative (elemental profile) analysis of sugar industry filter cake

\section{Description of Study Area}

The Wonji/Shoa sugarcane estate lies in the downstream of the Koka Dam in the Central Rift Valley of Ethiopia in the upper Awash river basin around $114 \mathrm{~km}$ from Addis Ababa within the geographical boundaries of $8021^{\prime}$ to 80 $29^{\prime} \mathrm{N}$, latitudes and $39012^{\prime}$ to $39018^{\prime} \mathrm{E}$, longitudes at an altitude of about 1,540 m above sea level. The district is also described as having a tropical wet climate with uniform warmth throughout the year and receives an average annual rainfall of $831.2 \mathrm{~mm}$, and the mean annual maximum and minimum temperatures are $27.6^{\circ} \mathrm{C}$ and $15.2^{\circ} \mathrm{C}$, respectively (Mulugeta et al. 2017; Sileshi and Osamu. 2017; Wendimu et al. 2015).

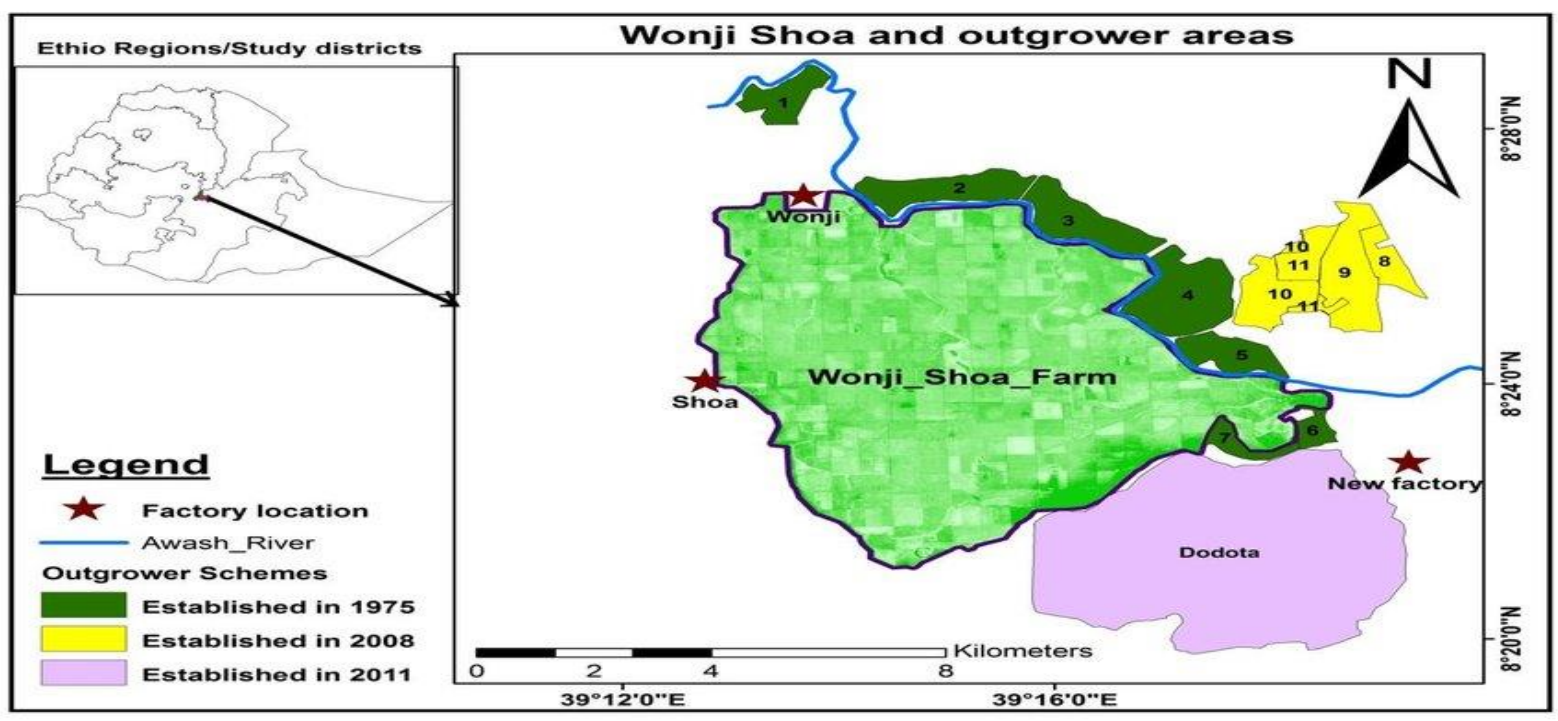

Figure 1 Location and topographic map of the study area [https://www.researchgate.net/figure/Map-of-Wonji-Shoasugar-factories] 


\section{Permissions to collect the raw materials}

The sample site (BNMRP, AARC, DZTIP, and wonji-shoa sugar industry) officer and the researcher communicated informal and they kindly permitted to collect the raw material and their co-operation can make this study a success.

\section{Sample Collection and Preparation}

\section{Collection and preparation of sugarcane filter cake}

Crude press mud samples were collected in polyethylene bag from wonji-shoa sugarcane mills of Ethiopia. The samples were sun dried, grinded, sieved of 200 mesh size and free from dirt. (Appendix 1.1)

\section{Collection of Agro-waste Residues}

The fresh teff (Eragrostis tef) and barley (Hordeum vulgare) straws and corn (Zea mays) cob samples were collected in plastic bag from the harvested of 2018 -19 of Debre Zeit teff improvement program (DZTIP) farmhouse, and breeder seed organization (located Debre Zeit Agricultural Research Center, Ethiopia), Assela Agricultural Research Center, Asela, Ethiopia and Bako National Maize Research Project (BARP) respectively.

\section{Preparation of Agro Waste Residues}

Teff \& barley straws and Corn cob were chopped and grinded (by employing laboratory chopper and grinder) and through a sieve of 200 mesh size. This made the uniform particle size of the straws and cob that were useful. The sieved powdered samples were stored in airtight polyethylene containers for future analysis (Appendix 1.2, 1.3 and 1.4) respectively.

\section{Analysis of Filter cake}

The collected filter cake sample was cleaned and made free from stones, dust, small metal particles and other unwanted particles by hand picking and magnetization. It was procured on the spot in industries; packed in plastic bags and transported within 2-3 hours to the laboratory of Ethiopian sugar corporation research and training center for further processing.

\section{Methods}

\section{Proximate Analysis of Prepared Raw materials}

Proximate composition of feed stocks (filter cake, teff \& barley straws, and corn cob) were analyzed including dry matter, crude ash, crude fat, crude protein and moisture content, using the procedures recommended by the 
Association of Official Analytical Chemists AOAC, (2000). Protein content was by employing elemental analyzer. Crude protein contains both true protein (amino acids) and non-protein nitrogen compounds.

\section{Moisture Content}

Moisture content (in w/w \%) was determined as recommended by AOAC, (2000). Accurately weighed $5 \mathrm{~g}$ (wet weight of sample) taken in a previously weighed glass dish and it was kept in a hot air oven at $110^{\circ} \mathrm{C}$ for 2 hours. Then the dried samples was cooled to room temperature in a desiccator and weighed again (taken as dry weight). The percentage of moisture content (MC) can be calculated as:

$$
\text { Moisture content (MC) } \%=\frac{\text { Wet weight }- \text { Dry weight }}{\text { Wet weight }} \times 100
$$

\section{Estimation of Dry Matter}

About $5 \mathrm{~g}\left(\mathrm{~W}_{1}\right)$ of samples were taken in pre-weighed moisture free cups and held overnight in a hot air oven at $102^{\circ} \mathrm{C}$.Then dried samples were weighed (taken as $\mathrm{W}_{2}$ ) and dry matter (DM) was calculated as:

Dry matter $(\mathrm{DM}) \%=\mathrm{W} 2 / \mathrm{W} 1 \times 100$

Where, $\mathrm{W}_{2}$-weight of the sample after drying; $\mathrm{W}_{1^{-}}$fresh weight of the sample

\section{Determination of Organic Dry Matter (ODM)}

Percent organic matter of samples were estimated by subtracting total ash of the respective from hundred as follows.

$$
\text { Organic dry matter (ODM) } \%=100-\text { Total ash }
$$

\section{Determination of Ash Content}

About $2 \mathrm{~g}\left(\mathrm{~W}_{1}\right)$ of samples were weighed accurately and placed in previously cleaned and weighted crucible $\left(\mathrm{W}_{2}\right)$. Then the crucible with samples were placed in a furnace and heated at $550{ }^{\circ} \mathrm{C}$ for 4 hours. The heating was done in such a way to prevent the loss of fluffy ash and it was cooled down to the room temperature using desiccators. Then the weight of the crucible with ash was measured (taken as $\mathrm{W}_{3}$ ). The ash content of each sample was calculated as:

$$
\text { Ash content }(\mathrm{AC}) \%=\frac{\mathrm{W} 3-\mathrm{W} 2}{\mathrm{~W} 1} \times 100
$$




\section{Fat Content of Feed Stocks}

The total fat content of feed stocks samples were determined by using AOAC, (2000) method. About 250 ml of $n-$ hexane was taken in two round bottom flasks (capacity, each $500 \mathrm{~mL}$ ) and were used for fat extraction. A soxhlet extractor was properly arranged (shown in Appendix 3a) on each of the round bottom flasks containing n-hexane. The dried samples (10 $\mathrm{g}$ of each trial) were then weighed accurately and taken into a thimble made with porous paper. The thimble was introduced into the extractor, and the fat extraction was performed for 4 hours at $80{ }^{0} \mathrm{C}$. Then, the solvent (n-hexane) was recovered under separation by using a rotary evaporator (see Appendix $3 b$ ). The fat residue was allowed to dry and its mass was recorded. The experiment was conducted three times to have triplicate measurements in order to avoid error. The total fat content was calculated as:

$$
\text { Fat content }(\mathrm{FT}) \%=\frac{\text { Weight of the fat residue }}{\text { Weight of the sample }} \times 100
$$

\section{Determination of Crude Fiber Content}

Accurately weighed $2 \mathrm{~g}\left(\mathrm{~W}_{1}\right)$ of defatted dried samples were then transferred to the separate $200 \mathrm{~mL}$ beakers. The digestion was carried out at $105{ }^{\circ} \mathrm{C}$ for an hour with $1.25 \% \mathrm{H}_{2} \mathrm{SO}_{4}(5 \mathrm{~mL})$ and $1.25 \% \mathrm{NaOH}(5 \mathrm{~mL})$ simultaneously and then washed with distilled water. The sample was then filtered through coarse perforated $(25$ $\mathrm{mm}$ ) crucibles under vacuum; the residues were dried at $95^{\circ} \mathrm{C}$ overnight using hot air oven, cooled to room temperature and kept in desiccators; weight of the dried samples were measured (taken as $\mathrm{W}_{2}$ ). Then, smashing was done by using a glass rod to reduce the size of the sample; it was then heated at $500^{\circ} \mathrm{C}$ for 2 hours, and cooled to room temperature in desiccators. Finally, it was weighed again and recorded as $\left(\mathrm{W}_{3}\right)$. The total crude fiber was expressed in percentage (AOAC, 2000) as:

$$
\text { Crud fiber } \mathrm{CF} \%=\frac{(\mathrm{W} 2-\mathrm{W} 3)}{\mathrm{W} 1} \times 100
$$

$\mathrm{W}_{1}$ - weight of sample $(\mathrm{g}) ; \mathrm{W}_{2}$ - weight of crucible and residue after drying $(\mathrm{g})$

$\mathrm{W}_{3}$ - weight of crucible and residue after incineration $(\mathrm{g})$

\section{Determination of Crude Protein by Elemental Analyzer}

Nitrogen content of samples was determined by employing CHNS-O elemental analyzer (Perkin Elmer 2400 CHSN-

O analyzer- Elemental Analyzer, Flash, 2000 Organic Elemental Analyzer). Samples were digested by using 
hydrochloric acid-water (1:1) mixture, and measured the total nitrogen (\%) of the sample. The protein content of the sample was determined by multiplying the total percentage of nitrogen with conversion factors of 6.25 as:

$$
\text { Total Protein }(P) \%=\% \text { of total nitrogen } * 6.25
$$

\section{Estimation of Total Carbohydrate in Feed Stocks}

The total carbohydrate content of samples was calculated by difference method (or subtraction method). Under this approach, summed the other constituents (protein, fat, moisture, ash) of the sample, which were determined individually, and these values are subtracted from the total weight of the samples. This is referred as the total carbohydrate that is calculated by using the following formula:

$$
\text { Total carbohydrate }(\%)=100-(\% \mathrm{p}+\% \mathrm{FT}+\% \mathrm{MC}+\% \mathrm{AC})
$$

Where: \% P-crude protein; \% FT- crude fat; \% MC- moisture content; \% AC- ash content

\section{Determination of Sucrose in the Filter Cake Sample}

Sugar content (pol/sucrose) in the filter cake feedstock was determined by measuring optical rotation in a polarimeter. About $10 \mathrm{~g}$ of sample was weighed and taken in a plastic beaker; water was then added and $50 \mathrm{~mL}$ $\mathrm{Pb}\left(\mathrm{NO}_{3}\right)_{2}$ solutions was added and stirred to settle out the heavy portion of filter cake. The slurry was then filtered and the clear solution injected in the polarimeter and the sucrose values were measured.

\section{Determination of $\mathbf{p H}$}

The $\mathrm{pH}$ of the sample (filter cake) was measured by using a digital $\mathrm{pH}$ meter (1400Crison, $\mathrm{pH}$ meter) with a reference of glass calomel electrode. About $10 \mathrm{~g}$ of powdered filter cake was placed into a $100 \mathrm{~mL}$ beaker containing $40 \mathrm{~mL}$ distilled water and stirred well for 5 minutes. Then, the $\mathrm{pH}$ of the filter cake solution was measured after calibration of the instrument using buffer solutions of $\mathrm{pH}$ (about 4 and 7) and recorded the $\mathrm{pH}$ of samples (ISO, 1994).

\section{Total Energy of the Feedstock and Prepared Feed}

The total energy of the sample was calculated by using the following formula according to (AOAC, 2000) method:

$$
\text { Total energy }\left(\frac{k c a l}{100 g}\right)=F T\left(9 \frac{k c a l}{g}\right)+C P\left(4 \frac{k c a l}{g}\right)+\text { carbohydrate }\left(4 \frac{k c a l}{g}\right)
$$

Where, FT is crude fat; $\mathrm{CP}$ is crude protein 


\section{Optimization of Sample Digestion for Mineral Analysis}

About $1 \mathrm{~g}$ of the sieved samples (filter cake and prepared feed ash of agro wastes) were weighed out and added into $100 \mathrm{~mL}$ conical flask. The sample was digested by the addition of $20 \mathrm{~mL}$ of a mixture of $\mathrm{HClO}_{4}(70 \%)$ and $\mathrm{HNO}_{3}$ (72\%), (3:1) this has taken as trial no.1(Table 1).The sample was digested for 2 hours in $100 \mathrm{~mL}$ conical flask that covered with watch glass, and reflux over a hot plate at $100^{\circ} \mathrm{C}$ (Abebe et al.2007). The digested sample was then poured into $50 \mathrm{~mL}$ beaker and $10 \mathrm{~mL}$ of distilled, deionized water was used to rinse the flask and watch glass and the digested sample was filtered through Whatman No. 42 filter paper; the solution was diluted in $50 \mathrm{~mL}$ volumetric flask up to the mark with distilled deionized water. Finally, two digested samples were kept in the refrigerator until the time of analysis. Blank solutions were made following the same digestion procedure as the sample. Triplicate for each bulk sample and sextet for the blank were digested. The digested samples were held back in the refrigerator, until all the metals in the sample solutions were determined by AAS. During digestion lanthanum chloride $20 \mathrm{~mL}$ ( 1 $\%$ ) was used as masking reagent to avoid refractory interference (for releasing calcium and magnesium from their phosphates). A similar procedure was adopted for trial no. 2 and 3 with different proportion of regents, different temperature and time that described in Table 1.

\section{Estimation of Mineral Contents}

The analysis of $\mathrm{Na}, \mathrm{Ca}, \mathrm{Mg}, \mathrm{K}, \mathrm{Fe}, \mathrm{Cu}, \mathrm{Zn}, \mathrm{Cd}, \mathrm{Cr}, \mathrm{Pb}$ and non-metals such as, $\mathrm{C}, \mathrm{S}, \mathrm{P}$ and $\mathrm{N}$ in digested samples of filter cake and prepared feed were determined by using FAAS (for minerals), UV-Vis (for P) and Elemental analyzer (for $\mathrm{C}, \mathrm{S}$ and $\mathrm{N}$ ). The standard solution was prepared for each analytes. The intermediate standard solution $(25 \mathrm{mg} / \mathrm{L})$ was prepared first by diluting $1000 \mathrm{mg} / \mathrm{L}$ of stock solution. Five appropriate working standard solutions of each of the metals were prepared from the intermediate standard solution. Intermediate standards, working standards and value of the correlation coefficient of the calibration curve (Appendix 2) for each metal are given in Table 1.

The values of the coefficient were obtained, which was observed as higher than 0.9957 indicating that good relationship between concentration and absorbance in the range. The analysis of metal adjustment of the operating condition is an essential part of the instrument techniques; hence the wavelength selection, silt and current flow for each analytes (shown in Table 2) was checked and the values were recorded for the estimation of each metal (DerJiun et al. 2012). 


\section{Determination of Phosphorus by using UV- Visible Spectroscopic Study Preparation of Stock solution}

Stock solutions were prepared accurately by using weighed amount of ascorbic acid $(44.0 \mathrm{~g})$ and ammonium molybdate $(25 \mathrm{~g})$ taken in two separate $500 \mathrm{~mL}$ volumetric flasks and dissolved in distilled water was added up to the mark. Then latter solution was transferred to $1 \mathrm{~L}$ flak and accurately weighed antimony potassium tartrate $(0.6 \mathrm{~g})$ and $300 \mathrm{~mL}$ of concentrated sulfuric acid were added to the ammonium molybdate solution, made up 1L, mixed well and labeled as a sulfuric - molybdate solution. The solutions were then kept for cooling and stored in a polyethylene or a pyrex bottle in a dark, refrigerated compartment. About $2.5 \mathrm{~mL}$ of ascorbic acid solution and $5 \mathrm{~mL}$ of sulfuric-molybdate solutions were taken into a $250 \mathrm{~mL}$ volumetric flask and distilled water was added up to the mark. It was allowed to stand for 15 minutes before use. The solution was stable for 2-3 days.

\section{Preparation of Standard Solution}

The phosphorus standard solution was prepared by accurately weighing the required amounts of ammonium dihydrogen phosphate $(0.9625 \mathrm{~g})$ which was then placed into a $250 \mathrm{~mL}$ volumetric flask and diluted with extraction reagent $(100 \mathrm{~g}$ of sodium acetate dissolved in a $1000 \mathrm{~mL}$ volumetric flask, along with $30 \mathrm{~mL}$ glacial acetic acid and then adjusting the $\mathrm{pH}$ to 4.8 by diluting with distilled water. The concentration of standard aliquots was taken as 250 mg P/L with extracting reagent.

\section{Estimation of Phosphorus (Morgan method)}

About $5 \mathrm{~g}$ of air-dried $2 \mathrm{~mm}$ mesh sieved scooped filter cake and prepared feedstock samples were placed into a 50 $\mathrm{mL}$ extraction vessel and then $25 \mathrm{~mL}$ extraction reagent were added and shaken well for 5 minutes, filtered and collected the extract immediately. The determination of phosphorus was done according to Shumaila and Mahpara (2009).The filtrate $(2 \mathrm{~mL})$ of extracted solution was then added to a $50 \mathrm{~mL}$ volumetric flask containing $23 \mathrm{~mL}$ of stock solution; it was mixed well and allowed to stand for 20 minutes, and then a blue color was developed. The absorbance was measured at $880 \mathrm{~nm}$ by a UV-Visible spectrophotometer using $1 \mathrm{~cm}$ cell against a blank (distilled water consisting extraction reagent).

\section{Estimation of Non-Metals by Using Elemental Analyzer}

Elemental analyzer (Perkin Elmer 2400 CHSN-O Organic Elemental Analyzer, Flash, 2000) was used in this study to determine the percent by weight of specific non-metals such as carbon, nitrogen, sulfur and hydrogen. Samples 
were digested by using 1:1mixture of hydrochloric acid and water. Then, the digested samples were used, for determining the concentration (\%) of carbon, sulfur and nitrogen and recorded the data.

\section{Fourier Transform Infrared (FTIR) Spectroscopic Study}

The FTIR Spectrometer (model: 8900, Shimadzu, Japan) was employed to determine the presence of functional group of feed components in filter cake and the prepared feedstock samples. FTIR spectra were recorded for both filter cake and the prepared feedstock. Here in this study, free biomass residue was removed by centrifuging the sample slurry at $110 \times 100 \mathrm{rpm}$ for 20 minutes by using mechanical centrifuge machine and the supernatant liquid was decanted. The obtained product was washed three times with distilled/deionized water. Then, the purified sample was dried and ground with $\mathrm{KBr}$ powder, subsequently made a pellet by employing pellet maker. Then, a perfect sample- $\mathrm{KBr}$ pellet of thin and transparent filmy sample was obtained. The FTIR spectrum of $\mathrm{KBr}$-sample pellet was carried out and the spectra were scanned (operated) in the range of $4000-400 \mathrm{~cm}^{-1}$ wave number at a resolution of $4 \mathrm{~cm}^{-1}$. 


\section{RESULTS and DISCUSSIONS}

Table 1 Proximate composition (in \%) of crude filter cake, Wonji-shoa, Ethiopia sugarcane mills and Agro-waste crop residues.

\begin{tabular}{|l|c|c|c|c|}
\hline \multicolumn{1}{|c|}{ Parameters } & Filter Cake & Teff Straw & Barley Straw & Corncob \\
\hline Dry matter & $89.5 \pm 0.5$ & $94.33 \pm 0.40$ & $91.93 \pm 0.2$ & $96.54 \pm 0.7$ \\
\hline Organic dry matter & $79.4 \pm 0.4$ & $89.46 \pm 0.18$ & $89.46 \pm 0.38$ & $98.33 \pm 0.3$ \\
\hline Moisture content & $10.5 \pm 0.5$ & $5.66 \pm 0.40$ & $8.07 \pm 0.2$ & $3.45 \pm 0.7$ \\
\hline Crude protein & $12.92 \pm 0.36$ & $2.32 \pm 0.58$ & $3.88 \pm 0.66$ & $2.98 \pm 0.47$ \\
\hline Crude fat & $10.5 \pm 0.82$ & $3.52 \pm 0.54$ & $2.32 \pm 0.22$ & $1.44 \pm 0.11$ \\
\hline Crude fiber & $29.52 \pm 1.00$ & $81.13 \pm 0.50$ & $85 \pm 0.5$ & $15.5 \pm 0.50$ \\
\hline Crude ash & $20.6 \pm 0.4$ & $10.53 \pm 0.18$ & $10.53 \pm 0.55$ & $1.69 \pm 0.03$ \\
\hline Carbohydrate content & 45.27 & 77.97 & 75.20 & 90.42 \\
\hline Energy content (Kcal) & 327.26 & 352.84 & 337.2 & 386.56 \\
\hline
\end{tabular}

* Values are expressed in mean \pm SD of triplicate experiment of each characteristic.

\section{The Proximate Analysis on Sugarcane Filter Cake}

The filter cake and Agro-waste crop residue samples were subjected to determination of the percentages of moisture, ash, water soluble and insoluble ash, nitrogen, protein, sugar and wax percentage according to the standard methods (AOAC 2000); A Manual of Laboratory Techniques 1992) with three replications and shown in Table 1.

The proximate analyses of filter cake included in this study (Table 1) showed that wonji-shoa sugar mill filter cake contains the highest proportion of dry matter $(89.5 \pm 0.5 \%)$ and it reveals that, this filter cake contain greater amount of nutritional organic matter $(79.4 \pm 0.4)$ and crude ash $(20.6 \pm 0.4 \%)$ which corresponds to inorganic matter called minerals. The moisture content and dry matter contents may vary depends on factors such as cultivator of cane, location, climate, dry length, soil pest diseases, cultivation practices and the cane processing method (Woolfe, 1992).

Some organic matter $(79.4 \pm 0.4 \%)$ was also found in the studied filter cake. The measured organic matter mainly consists more of organic carbon $(34.4 \pm 0.45 \%$ shown in table 4.3$)$ which is higher than some of the earlier reported 
values (Namita and Sharma, 2010) but agrees with certain reports (Gangarati et al. 2005). Organic matter (79.4 \pm 0.4 $\%)$ of the studied sample reveals that the filter cake contains the highest possible amount of proteins, fats, and carbohydrates (as fiber and sugars). Results of organic matter show that the filter cake is a useful feedstock raw material for animal feed production.

Accordingly, the currently studies the filter cake sample was dried in the sunlight and determined its moisture content as $(10.5 \pm 0.5 \%)$. Generally, lower moisture found in feed shows that their shelf life is enhanced. This helps in eliminating bacterial, fungal and other types of degradations (Abdul, 2017).

Higher amount of ash content found in this currently studied sugarcane filter cake is an indication of the greater mineral contents, which is also related to the nutritional value. Crude ash content $(20.6 \pm 0.4 \%)$ was found to be higher than reported (Gangarati et al, 2005) and in good agreement with the reported value (Moshfekus et al, 2012). Variation of ash contents is mainly due to different cultivation practices and alternations in clarification processes.

The percentage crude fiber in the studied filter cake sample is $29.52 \pm 1.0 \mathrm{~g}$. This value is significantly higher than that obtained by earlier (Suresh \& Reddy, 2011), who reported $13.73 \%$ of crude fiber content in an animal feed.

Nitrogen content $(2.06 \pm 0.39 \%)$ of the sample (filter cake) corresponds to the crude protein $(12.92 \pm 0.36 \%)$. The result shows that the crude protein in the present study was comparatively, higher than that reported earlier (Suresh and Reddy, 2011). As far as nitrogen content $(2.06 \pm 0.39 \%)$ is concerned the predominant form of nitrogen present in the filter cake was crude protein which is $(12.92 \pm 0.36 \%)$, and this protein level is slightly greater than the range 9.4-12.8\% obtained in the case of rotary vacuum filter cakes and considerably lower than the pies filter press containing protein $(15.5 \%)$. Almeida et al, (2007) stated that filter cake containing less than $20 \%$ protein, which could be less than $35 \%$ of dry matters are to be considered as digestible. The presently studied filter cake sample has $12.92 \pm 0.36 \%$ protein and $89.5 \pm 0.5 \%$ dry matter and hence shows digestible nutrients, and hence can be concluded that this feedstock (filter cake) is useful for animal feed preparation.

The dried sample of filter cake contains $89.51 \pm 0.5 \mathrm{~g}$ of dry matter and of this about $45.27 \mathrm{~g}$ corresponds to carbohydrate, made up mainly of fiber $(29.52 \pm 1.0 \mathrm{~g})$, sucrose $(3.85 \pm 0.83 \mathrm{~g})$, and the rest is constituted by other sugars. This carbohydrate content makes it a good source of energy, and hence a raw material (filter cake) fit for animal feed production. Its sucrose content refers that leads to effective biodegradation. The chemical composition of filter cake depends on the cane variety, land conditions, nutrients applied in the field, the process of clarification adopted and other environmental factors (Neha et al, 2011). 
In sugar industries press mud is usually dumped as garbage. Some sugar industries make use of it by converting it into compost. But this compost, along with its advantages, has some disadvantages too. It increases the wax content in the soil. The increase in wax reduces the porosity of the soil causing clogging. Thus, utilizing of filter cake in the production of animal feedstock is a safer option than composting (Sahu et al, 2016 and Peymaneh et al, 2014).

\section{The Proximate Analysis on Teff Straw}

The current investigation on teff straw was quantified as reported in earlier studies and as shown in Table 1 (Bonsi et al, 1995). They studied that about 2 hectares of farmland produces 12 tons of crop residues (grain yield $10 \mathrm{qt} / \mathrm{ha}$ with 2:1 straw to grain ratio) per annum in Ethiopia of which about one-third is left in the field for grazing (stubbles). The researcher stated that, feeding value of straw depends on intake and digestibility. For achieving a maximum intake of straw, crude protein content $(66-85 \mathrm{~g} / \mathrm{Kg})$ of dry matter (DM) is necessary. Maximum intake of DM has been observed another study (Bogale et al, 2008), when crop residues of 16-35\% has been included in the livestock diet.

The results of the proximate analysis of current study showed that the DM content of the teff straw is about $94.33 \pm 0.40 \%$. The DM of studied teff straw (agro-waste) was found as $>90 \%$, which corresponds to the earlier reported value (Njidda, 2010). The ash content of the teff straw in this study is about $10.53 \pm 0.18 \%$. The result is in line with the results for teff straw cultivated at a highland altitude of Gamela District, Southern Ethiopia, (Mengistu et al, 2016) and has slightly differed from the studies done by (Gashu et al, 2017), who reported the ash content of natural pasture $(4.5 \%)$. The ash content is generally recognized as measures of the quality of the assessment of functional properties of straws and feeds (Der-Jiun et al, 2012). The crop residues of teff straw had crude protein (CP) as $2.32 \pm 0.58 \%$. This result is lower than the FAO standard (FAO's 1984) and the threshold value of foodstuffs for $\mathrm{CP}$ is between 7-8 \%, which is tolerable for the sustenance of livestock and at the same time above the minimum for optimum rumen function. Those cereal crop residues are normally characterized by low digestibility and lower energy values, which are both inherent in their chemical composition. In this current study, the CP was determined and found to be lower than the reported value (Mengistu et al, 2016). The lower content of CP in crop residues may be corrected with the strategic supplementation of protein feeds to improve cattle performance. The organic dry matter (ODM) of teff straw was found to be $89.46 \pm 0.18 \%$, which is comparatively lower than that reported (Bonsi et al, 1995). Merely, the effects of organic matter on a dry base of the current subject field are easily harmonized with the reported (Andualem et al, 2015).Thus, the feed value of teff straw may be improve by fortification 
(blending) with some mineral and protein-rich ingredient like filter cake and could be tallied into the base feedstock (straws) in the formulation of animal feed is recommended.

Crude fiber and fat contents of teff straw were determined and found to be $81.13 \pm 0.50 \%$ and $3.52 \pm 0.54 \%$ respectively. Also it was estimated to be $>65 \%$ of fiber content. Singh and Oosting, (1992) stated that roughage feeds with crude fiber content less than $45 \%$ are categorized as high quality, those with 45-65\% fiber content are taken as medium quality and with more than $65 \%$ as low-quality fibers. Thus, presently studied teff straw can be categorized as low-quality roughages that may inflict limitations on productivity of animals. Hence, this study suggests that teff straw is an important feed stock for the preparation of animal feed by blending with other feed stocks. Both crude fat and fiber contents obtained in this study agree with the work reported earlier (Njidda, 2010).

\section{The Proximate Analysis on Barley Straw}

The barley straw feedstock is typically high in crude fiber (from both teff straw and corn cob), while lower in crude protein $(3.88 \pm 0.66)$ (Table 4.4), as compared to an earlier study (Gashu et al, 2017) which reported that the protein content of natural pasture $(7.5 \%)$ and in barley straw $(4.1 \%)$. To convert in to a forage supplement in situations where dietary energy or protein dilution is desired, blending with other protein rich feed stocks (i.e. filter cake of sugar industry) are required. Comparatively, barley straw has a greater amount of crude ash $10.53 \pm 0.55$ and moisture $8.07 \pm 0.2 \%$ than corn cob, and the former shows a lower quality composition and lower content of DM $(91.93 \pm 0.2 \%)$. It has been observed, that the ash composition of straws may be affected by the type of soil and climate conditions during the growth phase of the plant. Results of the present study are well in accordance with previous reports (Ivana et al, 2016). However, there are certain studies which report comparatively lower values (Anderson and Hoffman 2006; Sun et al, 2002).

The structural protein in the cell wall of the live plant remains as a part of the lignified cell wall in the case of straw. Variations in protein contents of different crop residues (shown in Table 4.4) depend on soil conditions, fertilization, harvest time and climatic conditions existing during the growth of the crop. Mostly protein contents are associated with other cell-wall constituents such as lignin, structural carbohydrates (fiber components like cellulose, pectin, and hemicelluloses), that are digested with the help of microorganisms in the hindgut, thus resulting poorly degradable

and digestible. Antongiovanni and Sargentini, (1991) reported that lower crude protein containing cereal straws range between $24-54 \mathrm{~g} / \mathrm{Kg}$ (on a dry basis). At the same time barley straw contains $36-44 \mathrm{~g} / \mathrm{kg}$ of protein 
(Hadjipanayiotou et al, 1997). The crude protein, content $3.88 \pm 0.66 \%$, found in the current study shows that the results can vary widely. The barley straw can be identified as one which contains low quantity of proteins.

Generally, high milk-producing cows require excellent quality forage that provides "effective" fiber in the rumen. Effective fiber stimulates chewing and ruminating, which are critical activities for thorough digestion and maintenance of stable pH in rumen. According to National Research Council (NRC, 2001) recommendation, a minimum of the total diet, with $75 \%$ of the crude fiber fraction provide the best forages for cattle. This level can maintain optimum rumen function and avoid potential milk fat depression, which occurs at reduced forage levels. Fiber concentrations in dairy cattle diets are variable because of the composition, source, and maturity of forages. Fiber content (in \%) discussed in the present study has been found as $85 \pm 0.5$, which is comparably similar with the reported values (Shaker et al, 2014). Furthermore, the barley straw currently studied has more crude fiber than the recommended value (NRC, 2001).

The crude fat content and dry organic matter of barley straw in this study are $2.32 \pm 0.22 \%$ and $89.46 \pm 0.38 \%$ respectively. These results are almost in agreement with the study reported earlier (Haddad, 2000) and (Anderson and Hoffman, 2006).

\section{The Proximate Analysis on Corncob}

A potential cob harvest on an average, has a relative yield of $19.7 \%$ of the grain mass, this result, almost agrees with the research reported (Blandino et al, 2016). Corn cob is the central rachis to which the grains are attached and which remains as an agro-industrial waste after threshing.

In this current study the nutritive value in terms of chemical composition of corn cob feedstuffs was carried out and it is given in Table 4.4. Proximate composition of corn cob in \% was found to be dry mater $96.54 \pm 0.7$, moisture content $3.45 \pm 0.7$, crude protein $2.98 \pm 0.47$, ash content $1.69 \pm 0.03$, crude fiber $15.5 \pm 0.5$, and crude fat $1.44 \pm 0.11$.

The measured values of crude protein, $2.98 \pm 0.47 \%$ in the presently studied corn cob is within the range of 2.40$3.35 \%$ similar to that reported by Adeyemi and Familade (2003) and also it is well in agreement with another earlier study (Aregheore, 2000). Corn cobs obtained from different varieties of maize (Zea mays); differ in proximate compositions owing to its variety, place of growth, type of soil and fertilizers, etc. However these values are lower than the value of crude protein, $3.54 \pm 0.15 \%$ and crude fat, $7.5 \%$ reported by Javid et al, (2015) and Kanengoni et al, (2015) respectively. This may be due to the varietal differences and post-harvest management of 
corncob. Crude fiber content was found as $15.5 \pm 0.50 \%$, which is lower than that reported by Kanengoni et al, (2015).

Some percentages of the abundant maize cob residues are now-a-days recycled, and used as composting material or as animal feed supplement instead of its low protein and fiber contents (Aregheore, 2000).

\section{Elemental Composition of Filter Cake}

Elemental composition of the filter cake of Dodota sugar mill of Wonji/Shoa was studied by employing FAAS, UVVisible spectroscopy and elemental analyzer; the results are shown in Table 2.

Table 2 Chemical compositions of Filter cake (wonji-shoa sugar mill)

\begin{tabular}{|c|c|}
\hline Elements & $\begin{array}{c}\text { Current study (ppm and } \\
\%)\end{array}$ \\
\hline $\mathrm{Ca}$ & 25.02 \\
\hline $\mathrm{K}$ & 43.87 \\
\hline $\mathrm{Na}$ & 20.89 \\
\hline $\mathrm{Mg}$ & 45.89 \\
\hline $\mathrm{Cu}$ & 1.89 \\
\hline $\mathrm{Zn}$ & 2.71 \\
\hline $\mathrm{Fe}$ & 34.33 \\
\hline $\mathrm{Cr}$ & 0.26 \\
\hline Co & 0.11 \\
\hline $\mathrm{Pb}$ & 0.17 \\
\hline $\mathrm{Cd}$ & 0.04 \\
\hline $\mathrm{P}$ & 43.1 \\
\hline $\mathrm{C}$ & $34.4 \pm 0.45 \%$ \\
\hline $\mathrm{S}$ & $9.93 \pm 0.23 \%$ \\
\hline $\mathrm{N}$ & $2.07 \pm 0.39 \%$ \\
\hline
\end{tabular}

*Filter cake (g/100 g DW) Mean \pm SD, for C, S and N in triplicate determinations on dry weight (DW) basis 
Table 2, shows the compositions of various elements described in parts per million (ppm) and in percentage. Filter cake samples contain up to $20.6 \pm 0.4 \%$ mineral matter (in terms of ash content), a large section of which may be calcium oxide, magnesium oxide and sulfur dioxide used for the treatment of raw juice during clarification. Filter cake has a highly variable composition due to the involvement of different agents. In fact, the chemical composition of filter cake depends on the cane variety; soil conditions, nutrients applied, the nature of precipitation or flocculation aids, temperature, fineness of filtration and clarification process adopted and other environmental factors. Therefore, the result shows that filter cake feedstock contains a substantial quantity of nutrients used for the formulation of useful products like animal feeds. The high loss on ignition values indicates that the samples contain more organic matter (s) (Suresh and Reddy, 2011).

The amount of calcium and phosphorus found in the present study are lower compared to the values reported (Reddy et al, 2004 and Bhosale et al, 2012). However, much higher sulfur (S) value was obtained $(9.93 \pm 0.23 \%)$ in comparison to earlier report (Gangavati et al, 2005). However, there are certain reports which are comparable with the present study (Moshfekus et al, 2012) $(7.36 \%$ ). This could be due to the fact that the presently studied filter cake is processed under sulphatized condition during clarification or processing.

The micro-mineral iron content in the presently studied sample (filter cake) was found as $34.33 \mathrm{ppm}$ which is much lower compared to the reported ranges (Reddy et al, 2004 and Suresh and Reddy 2011). Copper remained slightly lower than the previously published values (Suresh and Reddy, 2011 and Reddy et al, 2004). The available zinc (2.71 ppm) in the presently studied sample was found to be lower compared to the values reported (Reddy et al, 2004 and Suresh and Reddy 2011) as $86.5 \mathrm{ppm}$. The cobalt and manganese percentage in the filter cake of the present study were also found lower as compared to the literature values, which were studied (Reddy et al, 2004), and (Suresh and Reddy, 2011). Such differences might be due to a seasonal variation during cane cultivation, the maturity of cane, soil and agro-climatic conditions and the process followed in the clarification of sugarcane juice (Sahu et al, 2016).

\section{Fourier Transform Infrared (FTIR) Spectroscopic Analysis on filter cake}

The characteristic functional group of nutritional constituents of the components of filter cake was analyzed and the resulting FTIR spectrum is given as Figure 1. 


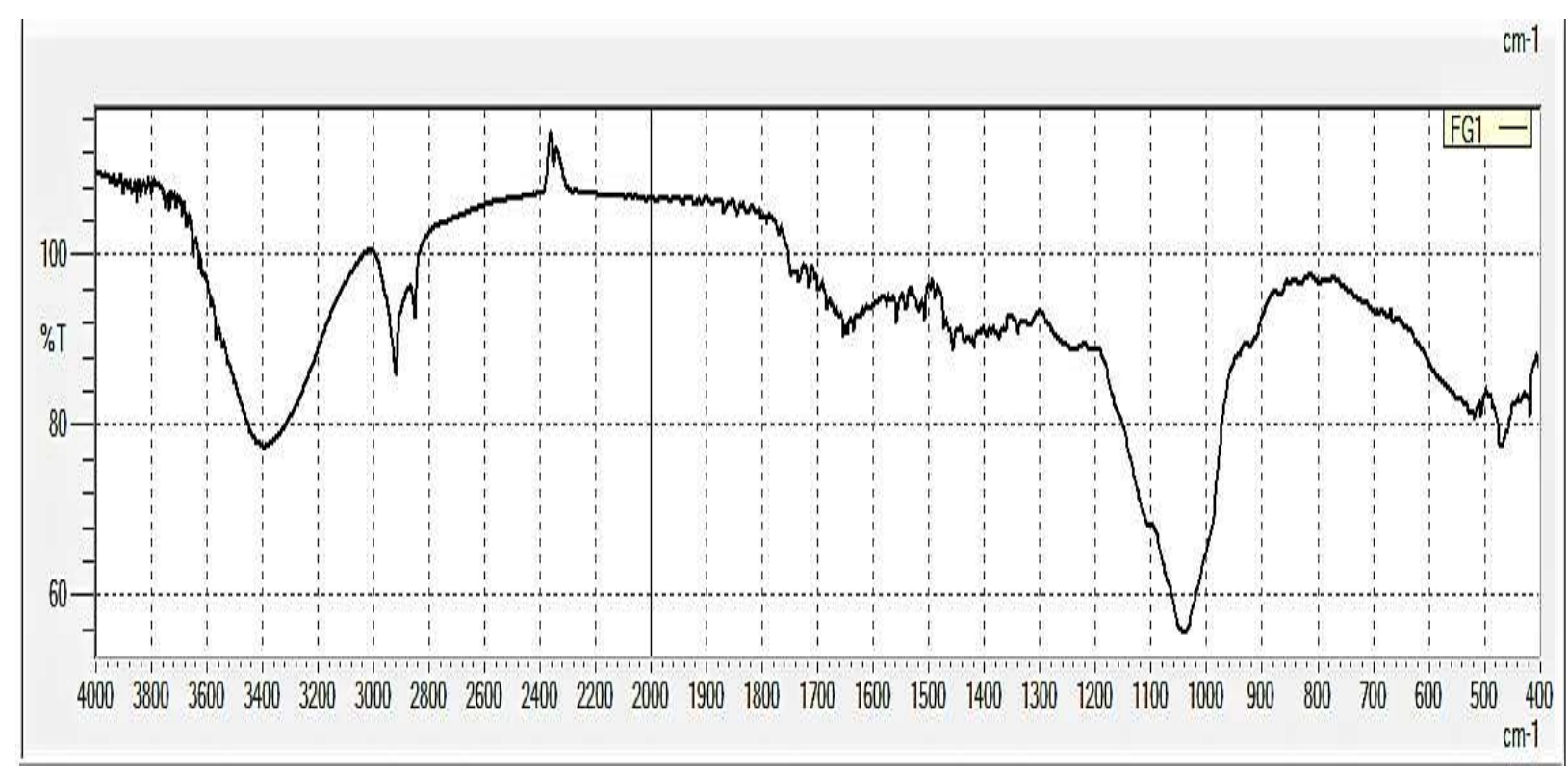

Figure 1 FTIR spectrum of filter cake.

The spectrum of FTIR shows a broadband between $3250-3500 \mathrm{~cm}^{-1}$ which indicates the presence of both free and hydrogen-bonded $\mathrm{OH}$ groups. The stretching appeared at $2918 \mathrm{~cm}^{-1}$ indicates the aldehyde (CHO) group on the surface (Moshfekus et al, 2012). The stretching of $\mathrm{OH}$ groups bonded to methyl shows a signal between $2849 \mathrm{~cm}^{-1}$ and $2916.5 \mathrm{~cm}^{-1}$, which can represent the tetrahedral carbon of an alkane that could be attributed to the long-chain fatty acid/different amino acids of protein of the feed. Similarly, the signal at $1685 \mathrm{~cm}^{-1}$, could represent the $\mathrm{C}=\mathrm{O}$, groups stretching of acid/ester; this may indicate the availability of fat or fatty acid in the studied feed stocks raw material filter cake. The IR spectra of the presently studied samples show a weak and broad peak at about 1645.5 $\mathrm{cm}^{-1}$, which corresponds to the (-C-N) group, which can represent an amide group containing feed ingredient, and the peak appeared at $1456.3 \mathrm{~cm}^{-1}$ is indicative of $-\mathrm{CH}_{3}$ group. The $\%$ transmittance has appeared at $1039.7 \mathrm{~cm}^{-1}$ and it shows the presence of aliphatic amines and the broad band stretching between the ranges of $1200-900 \mathrm{~cm}^{-1}$, indicates the presence of inorganic compounds, which could be $\mathrm{SiO}_{4}{ }^{2-}$. This is supported by Moshfekus et al, (2012), who stated that the results of IR spectrum are quite helpful in the identification of various forms of minerals present in the samples. The presently studied IR spectrums of the sample do not show any constructive signals at $2130 \mathrm{~cm}^{-1}$ $\& 1650 \mathrm{~cm}^{-1}$ corresponding to free water molecules. It reveals that the dried filter cake is considerably free from moisture. 


\section{CONCLUSIONS}

The physicochemical characterization (proximate analysis) of filter cake and crop residue feed stocks were evaluated and drawn the following conclusions. The important organic constituents of filter cake including sugar $(3.85 \pm 0.83 \%)$, fiber $(29.52 \pm 1.00 \%)$ and protein $(12.92 \pm 0.36 \%)$ were also determined. The FTIR analysis of filter cake showed that it is useful feedstock that contains various feed functional constituents and mineral analysis also presents the results are quite helpful in the identification of various forms of minerals present in the samples.

Overcoming the lacking in feedstocks raw material in quality, quantity and low cost with macro and micro constituent rich sugar industry byproduct, filter cake is one of the major contributory for the development of feed industry in the country, Ethiopia. This makes also a good opportunity to decrease the waste in such industries.

There are too many areas in developing countries where ruminant livestock starves due to lack of feed. So this study shows that the direction of searching and compensating the availability of such important croup residues and the sugar industry by product (filter cake) as the raw sources of livestock feeds.

\section{List of abbreviations}

AARC

AAS

AFOs

AOAC

BNMRP

CCRs

CF

$\mathrm{CP}$

DIP

DM

DTA

DTG

DZTIP

EAFIA
Ambo Agricultural Research Center

Atomic Absorption Spectrophotometer

Animal Feeding Operations

Association of Official Analytical Chemists

Bako National Maize Research Project

Cereal Crop Residues

Crude Fiber

Crude Protein

Degradable Intake Protein

Dry Matter

Differential Thermal Analysis

Derivative Thermo Gravimetric

Debre Zeit Teff Improvement Program

Ethiopian Animal Feed Industry Association 


$\begin{array}{ll}\text { FAO } & \text { Food and Agriculture Organization } \\ \text { FT } & \text { Crude Fat } \\ \text { FTIR } & \text { Fourier Transform Infrared Spectroscopy } \\ \text { MARC } & \text { Melkasa Agricultural Research Center } \\ \text { NRC } & \text { National Research Center } \\ \text { PM } & \text { Press Mud } \\ \text { ppm } & \text { Parts Per Million } \\ \text { SD } & \text { Standard deviation } \\ \text { SPM } & \text { Sugarcane Press Mud } \\ \text { SPR } & \text { Sugarcane Press Residue } \\ \text { SSF } & \text { Solid State Fermentation } \\ \text { TDM/ha } & \text { Tone of Dry Mater per Hectare } \\ \text { TG } & \text { Thermal Gravimetric } \\ \text { UIP } & \text { Undergirded Intake Protein } \\ \text { UN } & \text { United Nation } \\ \text { W/W } & \text { Weight by Weight } \\ \text { USDA } & \text { United State Department of Agriculture }\end{array}$

\section{DECLARATIONS}

\section{Ethics Approval and Consent to Participate}

Not applicable

\section{Consent for Publication}

Not applicable

\section{Authors' Contributions}

A. Abera; Study conception and design, Acquisition of data and Drafting of manuscript. A. Abera and R. Duraisamy; Analysis and interpretation of data. S. Badessa and R. Duraisamy; Critical revision.

\section{Availability of Data and Materials}

All the data materials were listed under the appendices

\section{Competing Interests}


The authors declare that they have no competing interests.

\section{Funding}

This research received no specific grant from any funding agency in the public, commercial, or not-for-profit sectors.

\section{Acknowledgments}

Authors gratefully express their sincere thanks to the Department of Chemistry, College of Natural Science for giving the laboratory permission to conduct the research work. The authors also acknowledge the help of BNMRP, AARC, DZTIP, Ethiopian sugar cooperation, and wonji-shoa sugar industry during the investigation.

\section{RECOMMENDATIONS}

The future importance of agricultural by-products as feeds for livestock, particularly fibrous by-products for ruminants, is acknowledged, identifying ways of overcoming constraints to their greater utilization as feed is therefore an appropriate theme for the present research. And this study shows the direction for researcher to overcome such difficulties. 


\section{REFERENCES}

Abubakar US, Yusuf KM, Safiyanu I, Abdullahi S, Saidu SR, Abdu GT, and Indee AM. Proximate and mineral composition of corn cob, banana and plantain peels. International Journal of Food Science and Nutrition. 2016; 1(6): $25-27$.

Adeyemi O.A. and Familade F.O. Replacement of maize by rumen filtrate fermented corn-cob in layer diets. Bioresource Technology. 2003; 90: 221-224.

Almeida B. A. D. L., Barreto, G. F. \& Gonçalves C. M. N. Resíduos da agroindústria canavieira no estado de minas gerais: Usos e conservação ambiental. Informe Agropecuário. Belo Horizonte, 2007; 28(239): 96-100.

Andualem Tonamo, Gebeyehu Goshu and Berhan Tamir. Assessment of Cattle Feed Resources Chemical Composition and Digestibility of Major Feeds in Essera District, Southern Ethiopia. Science, Technology and Arts Research Journal. 2015; 4(2): 89-98.

Antongiovanni M., Sargentini C. Variability in chemical composition of straws. Fourrages etsous-produits méditerranéens Ciheam. 1991; 16: 49-53.

Aregheore, E. M. Chemical composition and nutritive value of some tropical by-product feedstuffs for small ruminants- in vivo and in vitro digestibility. Animal Feed Science and Technology. 2000; 85: 99-109.

Beauchemin, K.A. and L.M. Rode. Minimum versus optimum concentrations of fiber in dairy cow diets based on barley silage and concentrates of barley or corn. Journal of Dairy Science. 1997; 80(8): 1629-1639.

Bistanji, G., Hamadeh, S., Hajj Hassan, Tami, F. and Tannous, R. The potential of agro-industrial byproducts as feeds for livestock in Lebanon. Livestock Research for Rural Development. 2000; 12(3): $422-445$.

Bogale Solomon, Melaku Solomon and Yami Alemu), Potential use of crop residues as livestock feed resources under smallholder farmers conditions in bale highlands of Ethiopia. Tropical and Subtropical Agroecosystems, 2008; 8(1): 107-114 
Bonsi M.L.K., Osuji P.O., Tush A.K. Effect of supplementing teff straw with different levels of leucaena or sesbania leaves on the degradabilities of teff straw, sesbania, leucaena, tagasaste and vernonia and on certain rumen and blood metabolites in Ethiopian Menz sheep. Animal Feed Science and Technology. 1995; 52: 101-129.

Dayana Alves da Costa, Clebson Lucas de Souza, Eloísa de Oliveira Simões Saliba and Jailton da Costa Carneiro. By-products of sugar cane industry in ruminant nutrition"; International Journal of Advanced Agricultural Research. 2015; 3: 1-9.

Der-Jiun Ooi, Shahid Iqbal and Maznah Ismail. Proximate Composition, Nutritional Attributes and Mineral Composition of Peperomia pellucida L. (Ketumpangan Air) Grown in Malaysia. Molecules. 2012; 17: 11139-11145.

Gangavati, P.B., M.J. Safi, A. Singh, B. Prasad, I.M. Mishra.Pyrolysis and thermal oxidation kinetics of sugar mill press mud. Thermochemica Acta. 2005; 428: 63-70.

Gangavatib, P.B., M.J. Safia, A. Singha, B. Prasada and I.M. Mishra. Pyrolysis and thermal oxidation kinetics of sugar mill press mud. Thermochimica Acta, 2005; 428: 63-70.

Gashu Geremew, Tegene Negesse and Aster Abebe. Assessment of Availability and Nutritive Values of Feed Resources and their Contribution to Livestock Nutrient Requirements in Chire District, Southern Ethiopia. Agricultural Research and Technology, 2017; 7(4): 1-5.

Haddad S.G. Associative effects of supplementing barley straw diets with alfalfa hay on rumen environment and nutrient intake and digestibility for ewes. Animal Feed Science and Technology, 2000; 87: 163-171.

Hadjipanayiotou M., Economides S., Kyprianou G., Antoniou I. and Photiou A. Feeding urea treated barley straw to growing Friesian heifers. Livestock Research for Rural Development, 1997; 9(4): 1-13.

Ivana Plazoni, Željka Barbarić-Mikočević and Alan Antonovi. Chemical Composition of Straw as an Alternative Material to Wood Raw Material in Fibre Isolation. Drvna Industrija. 2016; 67 (2); 119-125.

Javid Farooq, Ramesh Kumar Sharma, Ankur Rastogi and Keshab Barman. Effect of Replacement of Wheat Straw with Maize Cobs with or without Physico-Chemical Treatment on Degradation of Dry Matter, Truly Digestible 
Organic Matter and Production of Microbial Biomass of Composite Ration in Vitro using Goat Rumen Liquor. Journal of Animal Research. 2015; 5(3): 501-510.

Kanengoni A. T., Chimonyo M., Ndimba B. K., and Dzama K. Potential of Using Maize Cobs in Pig Diets - A Review"; Asian Australas Journal of Animal Science. 2015; 28(12): 1669-1679.

Massimo Blandino, Claudio Fabbri, Mariangela Soldano, Carlo Ferrero ,Amedeo Reyneri. The use of cobs, a byproduct of maize grain, for energy production in anaerobic digestion. Italian Journal of Agronomy. 2016; 11(754): 195-198.

Mengistu Lemma, Tegene Negesse and Ajebu Nurfeta Assessment of Feed Resource Availability and Quality in Kedida Gamela District, Southern Ethiopia"; International Journal of Environment, Agriculture and Biotechnology, 2016; 1(1): 1-9.

Moreira I., Marcos Júnior M., Furlan A. C., Patricio V. M. I. and Oliveira G. C. Use of sugar cane yeast (Saccharomyces spp.) dried by spray-dryer as protein source on growing-finishing pigs feeding"; R. Bras. Zootec. 2002; 31(2): 962-969.

Moshfekus Saleh-e-In Md., Salma Yeasmin, Bishwagith Kumer Paul, Mainul Ahsan, Zamilur Rahman Md., and Sudhangshu Kumar Roy. Chemical Studies on Press Mud: A Sugar Industries Waste in Bangladesh. Sugar Technology. 2012; 14(2): 109-118.

Namita Joshi and Sonal Sharma. Physico-Chemical Characterization of Sulphidation pressmud. Composted pressmud and Vermicomposted pressmud, 2010; 2(3): 79-82.

Neha G, Sumit T \& Chandrajit B), “Characterization of press mud”; A sugar industry waste, Fuel. 2011; 90 (1): 389394.

Njidda A. A. Chemical Composition, Fiber Fraction and Anti-Nutritional Substances of Semi-arid Browse Forages of North-Eastern Nigeria. Nigerian Journal of Basic and Applied Science. 2010; 18 (2): 181-188.

NRC. Nutrient Requirements of Dairy Cattle. Sixth Revised Edition. National Academy Press. Washington DC. 2001. 
Nyonje E. O, Njogu P. and Kinyua R. Assessment of the potential for utilization of sugarcane derived press mud for biogas generation in South Nyanza sugarcane zones, Kenya. International Conference on Sustainable Research and Innovation. 2014; 5: 48-51.

Peymaneh Ghasemi Afshar, Masoud Honarvar, Maryam Gharachorloo, Parvin Eshratabadi, Behzad Bazyar. Investigation of the Physico-Chemical Properties of Press Mud: A Sugar Industry Waste. Advances in Environmental Biology, 2014; 8(13): 1053-1058.

Rouf M. A., Islam M. S., Bajpai P. K. and Jotshic C. K., "Techno-economic assessment of biogas production from press mud in Bangladesh”; Bangladesh J. Sci. Industrial Research. 2013; 48(1): 51-58.

Sahu S., Patel B.H.M., Malapure C.D., Ankita, Singh M., Verma A.K., Singh G. and Bhusain B. Screening of sugarcane press mud as a potential alternative feed for livestock. Indian Journal of Animal Research. 2016; 50 (2): 207-210.

Shaker Abdulameer Hassan, Khasraw Muheddin Hassan and Sarwar Mohammed Sadq. Effect of Feeding Chemically and Biologically Treated Barley Straw on Some Hematological and Serum Biochemical Parameters of Karadi Lambs. Annual Research and Review in Biology. 2014; 4(21): 3227-3237.

Shumaila Gul and Mahpara Safdar. Proximate Composition and Mineral Analysis of Cinnamon. Pakistan Journal of Nutrition, 2009; 8(9): 1456-1460.

Singh, G.P. and Oosting S.J "A model for describing the energy value of straws. Indian dairyman. 1992; 44: 322327.

Sun R.C., Sun X.F., Fowler P. and Tomkinson J. Structural and physico-chemical characterization of lignins solubilized during alkaline peroxide treatment of barley straw. European Polymer Journal. 2002; 38: 1399-1407.

Suresh, B.N. and B.S.V. Reddy. Dried Sugarcane Press Residue as a Potential Feed Ingredient Source of Nutrients for Poultry. Asian-Aust. Journal of Animal Science. 2011; 24(11): 1595-1600.

Tom Anderson and Patrick Hoffman. Nutrient Composition of Straw Used in Dairy Cattle Diets. Focus on Forage. 2006; 8(1): 1-3. 
Viljoen M., Brand R. S. and Hoffman L.C. Differences in' the chemical composition and digestibility of cereal hay and straw produced in a Mediterranean rainfall area of South Africa. South African Journal of Plant and Soil. 2005; 22(2): 106-109.

Https://www.researchgate.net/figure/Map-of-Wonji-Shoa-sugar-factories-factory-operated-plantation-and-plots-ofoutgrowers_fig1_299378253 [accessed 1 Aug, 2020] 


\section{APPENDICES}

\section{Appendix I. Preparation of Feedstock Raw Materials}

Appendix 1.1: Preparation of Filter Cake (a) Fresh Filter cake, (b) Sun dried Filter cake,

(c) Grinded Filter cake and (d) Sieved and labeled filter cake

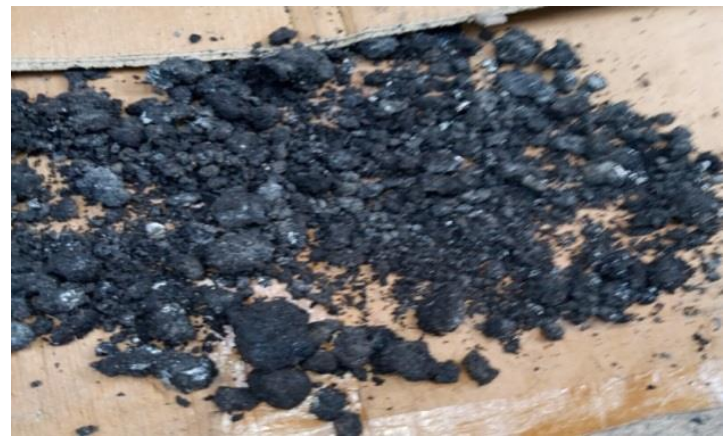

(a)



(c)

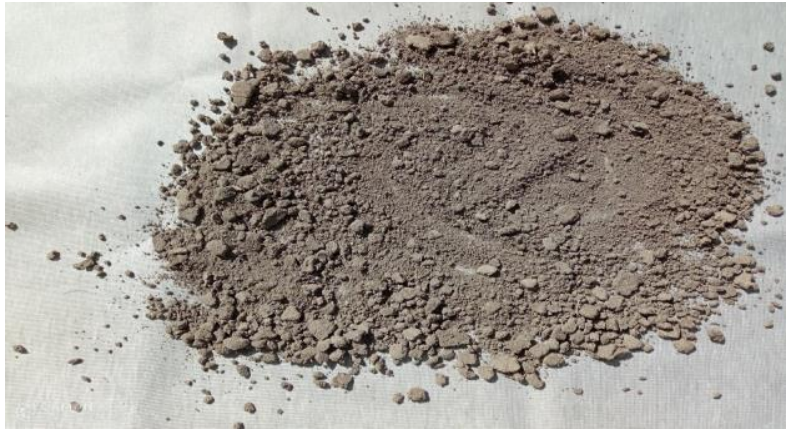

(b)

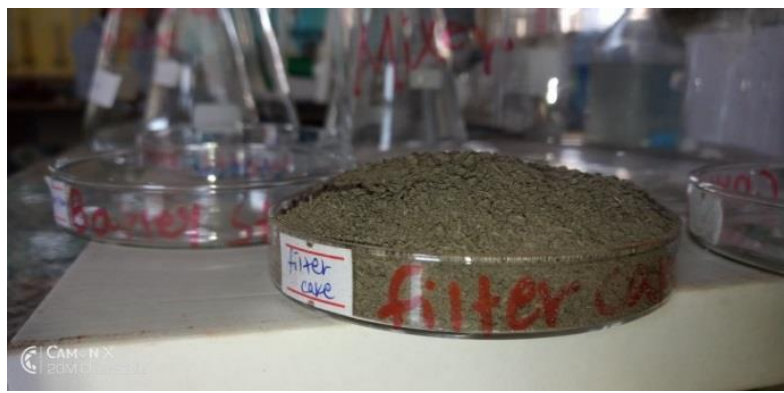

(d)

Appendix 1.2:Preparation of Teff Straw (a) Mechanically chopped and grinded teff straw, (b) grinded sieving teff straw, (c) Sieved teff straw and (d) Labeled teff straw

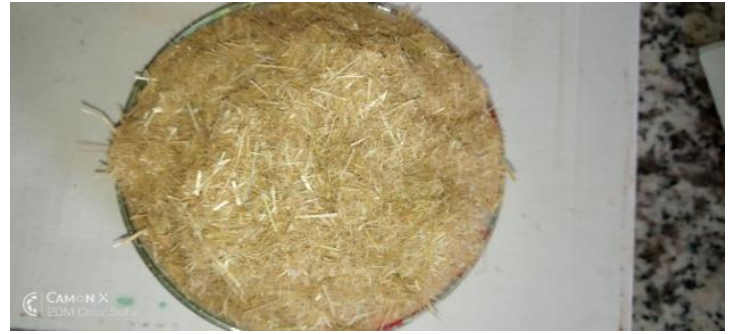

(a)

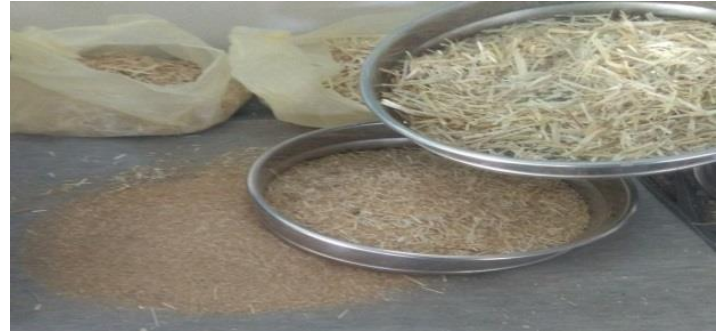

(b) 


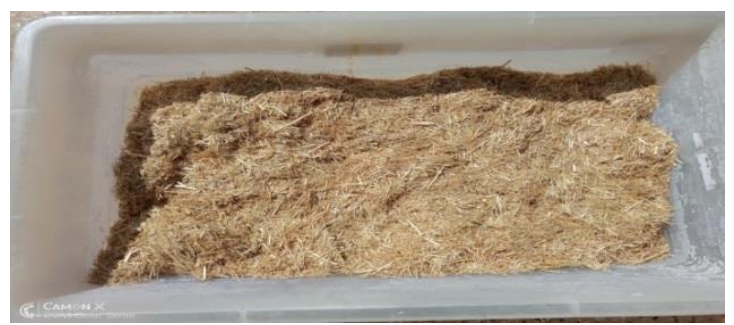

(c)

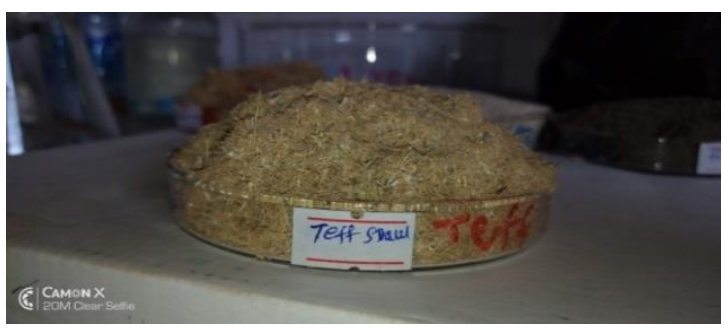

(d)

Appendix 1.3: Preparation of Barely Straw(a) Barley straw at the farm, (b) Grinded and sieving of barely straw,

(c) Sieve separated barely straw and (d) Labeled barely straw

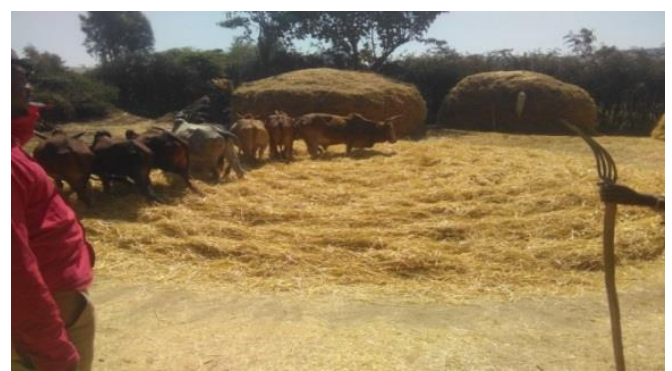

(a)

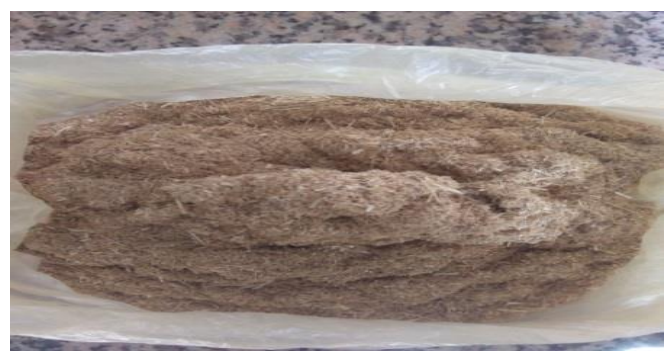

(c)

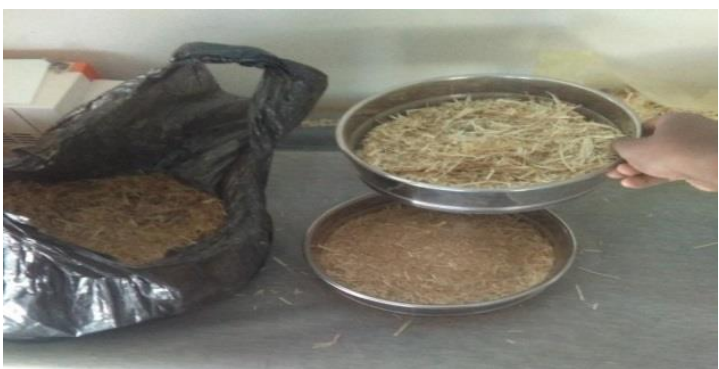

(b)

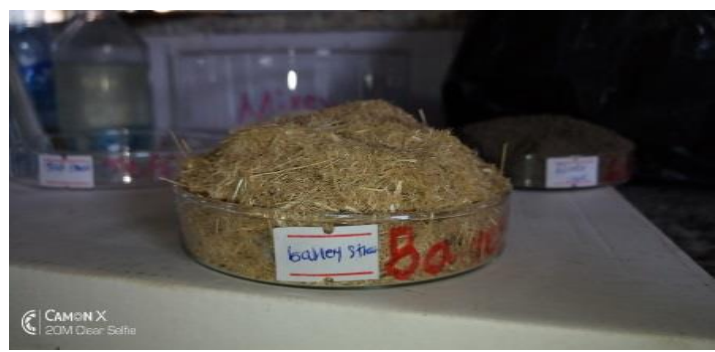

(d)

Appendix 1.4:Preparation of Corncob (a) Corn cob sample, (b) Chopped corn cob, (c) Grinded corn cob, (d)

Sieved corn cob and (e) Labeled Corn cob

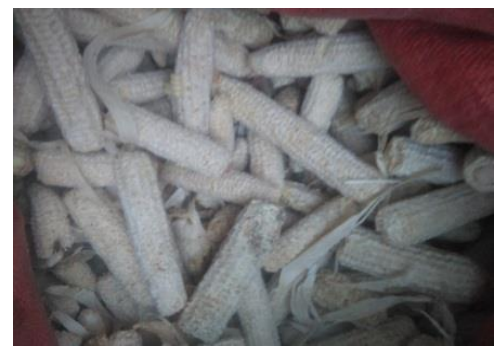

(a)

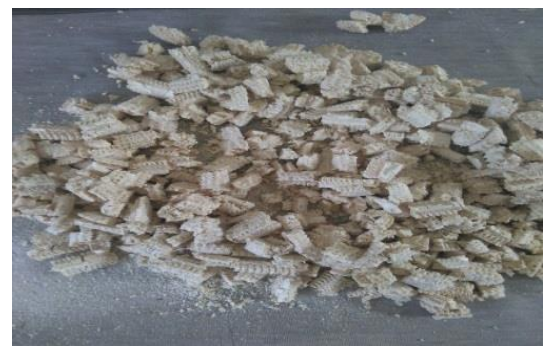

(b)

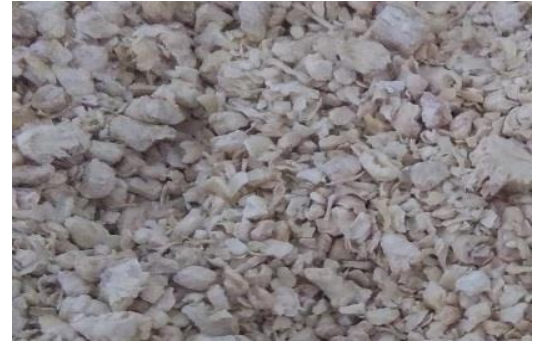

(c) 


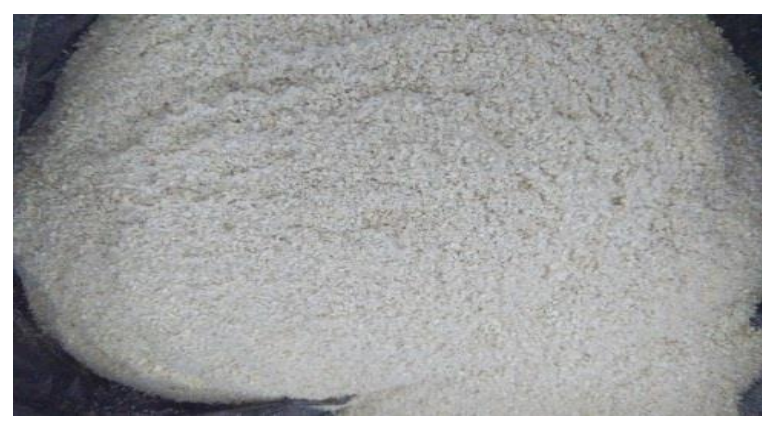

(d)

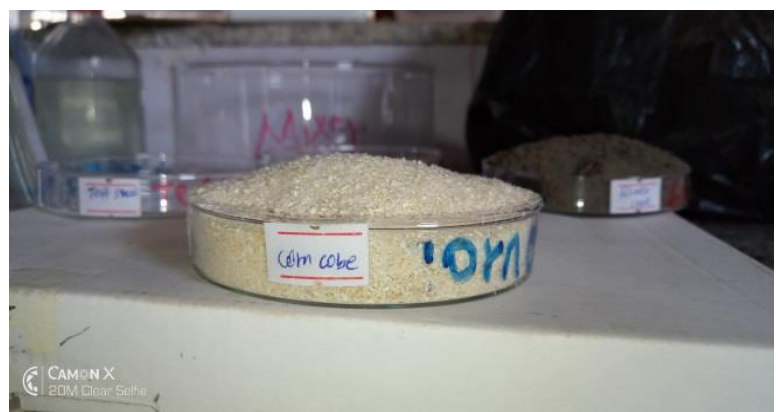

(e)

Appendix 2: The Calibration Graph of each of Metals of interest
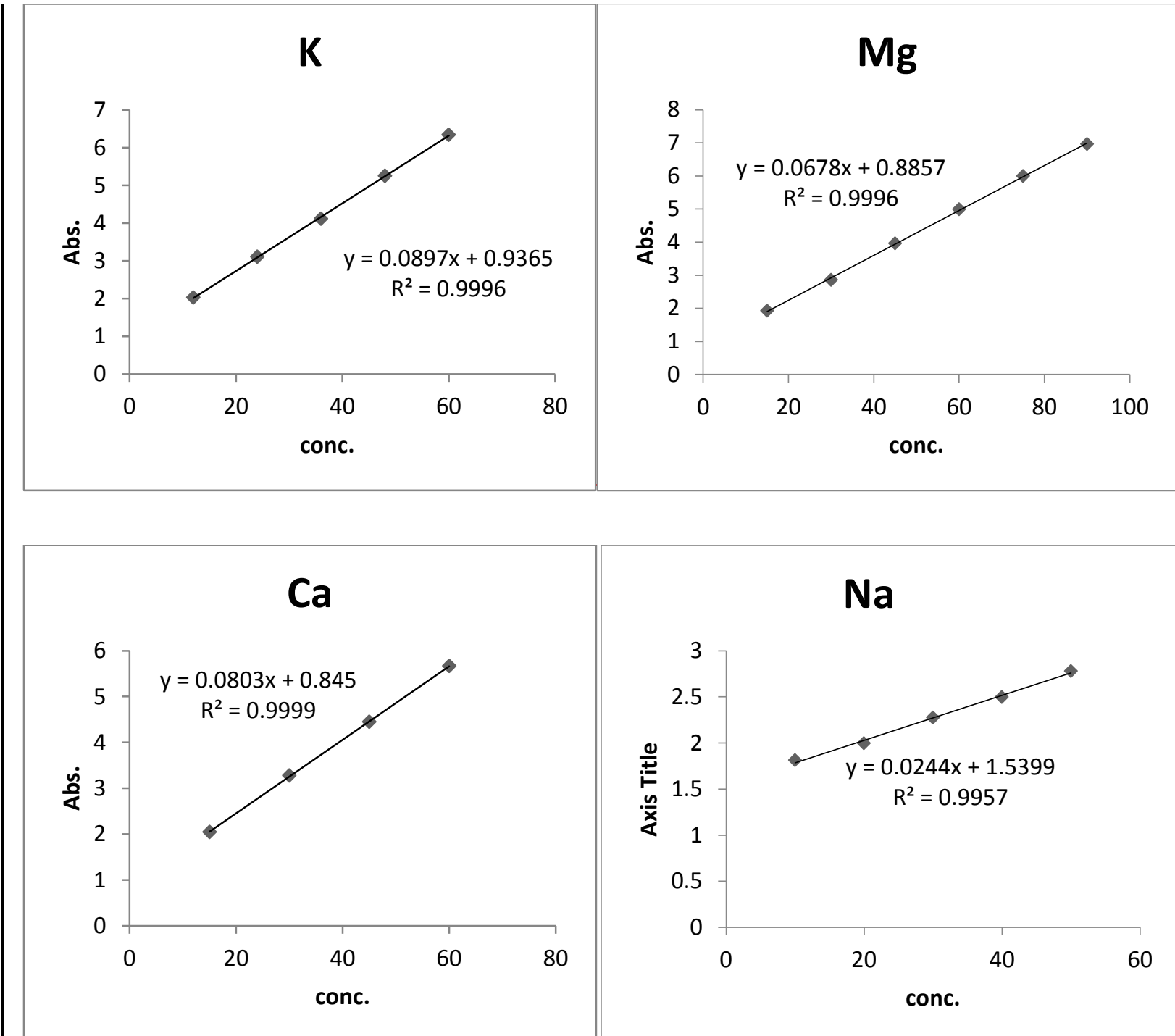

$\mathrm{Na}$

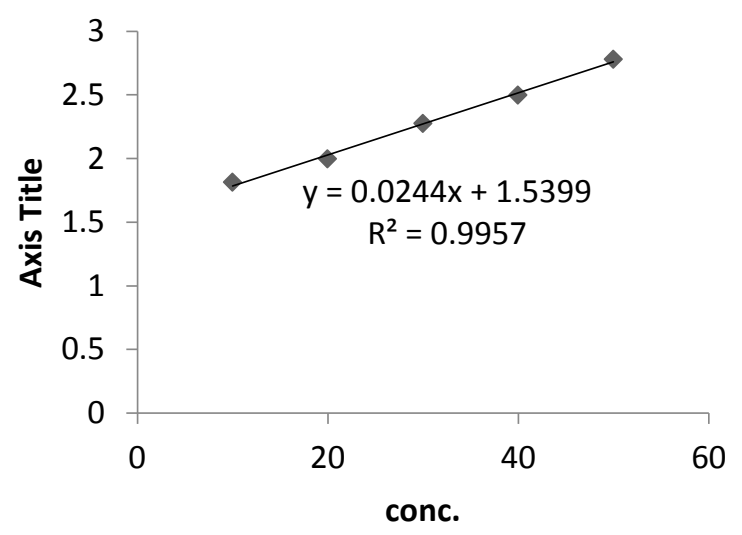



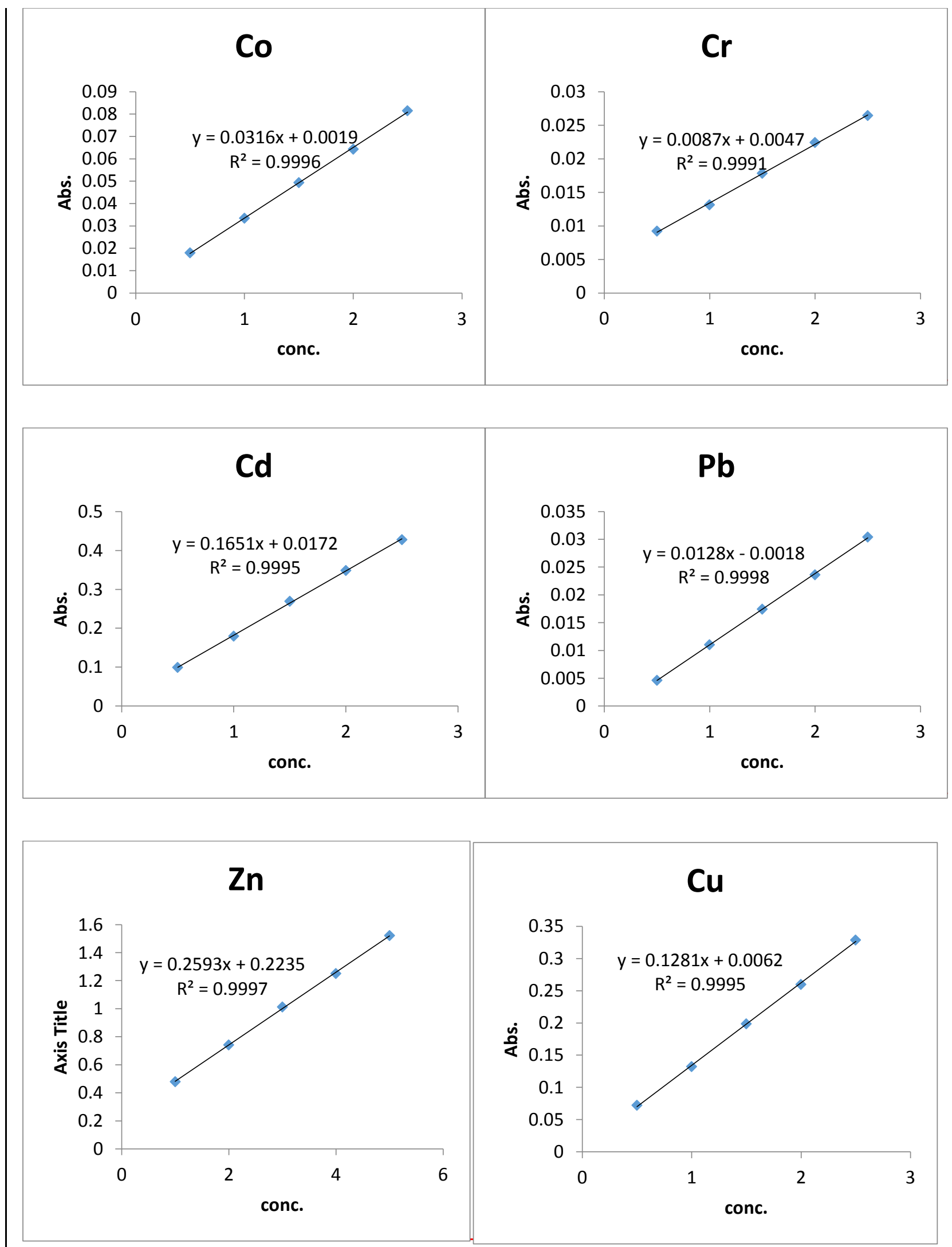

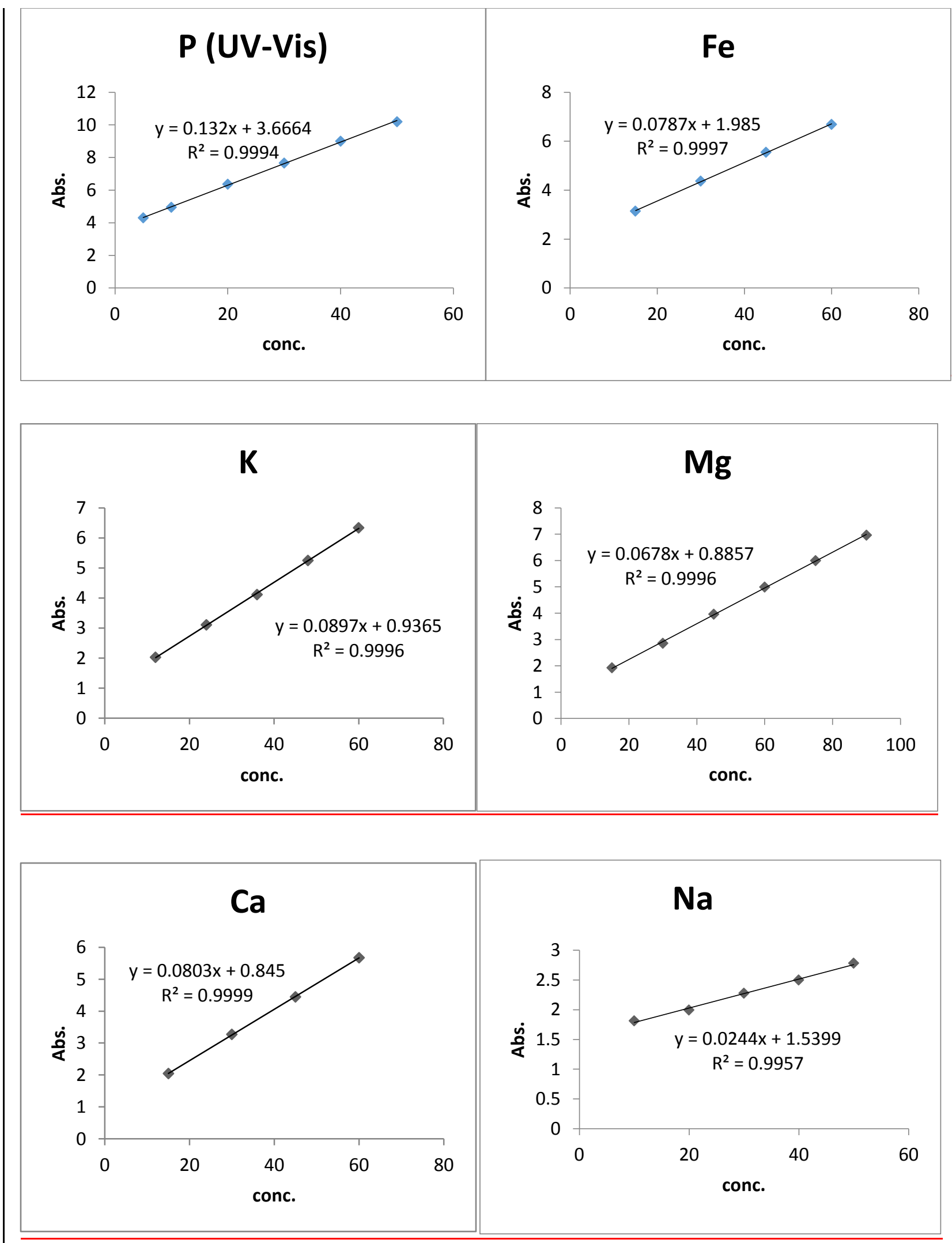

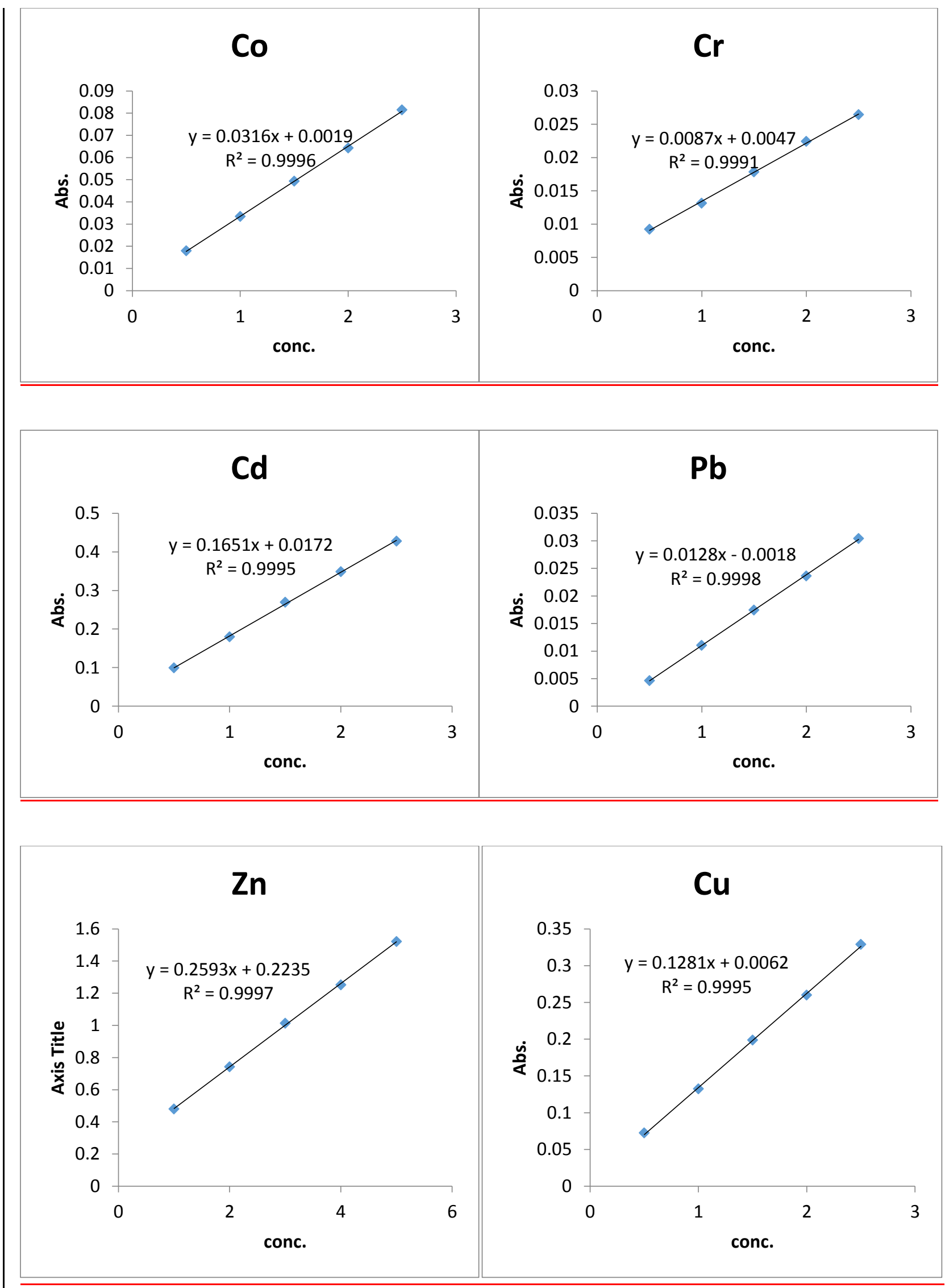


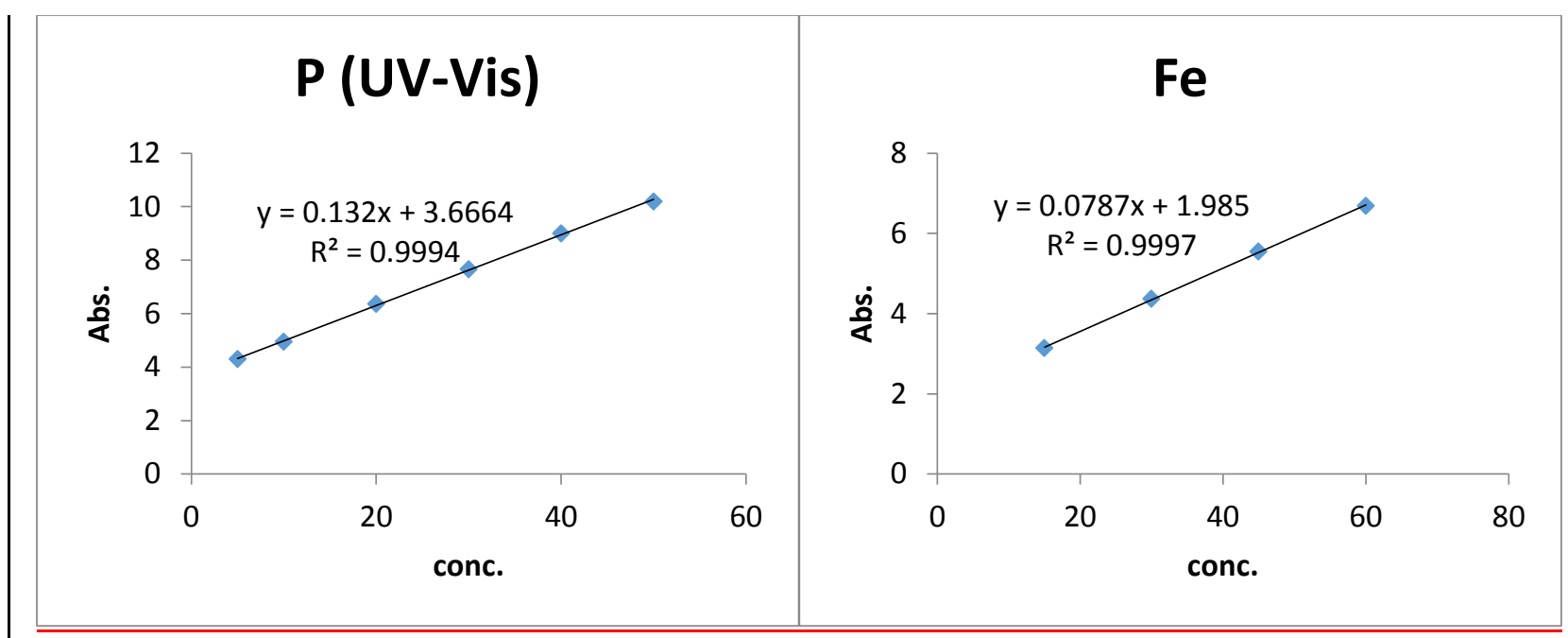

Appendix 3: Crude Fat determination (a) Soxthlet extraction (Crud Fat extraction) and (b) Rotary Evaporator (for crud fat separation)

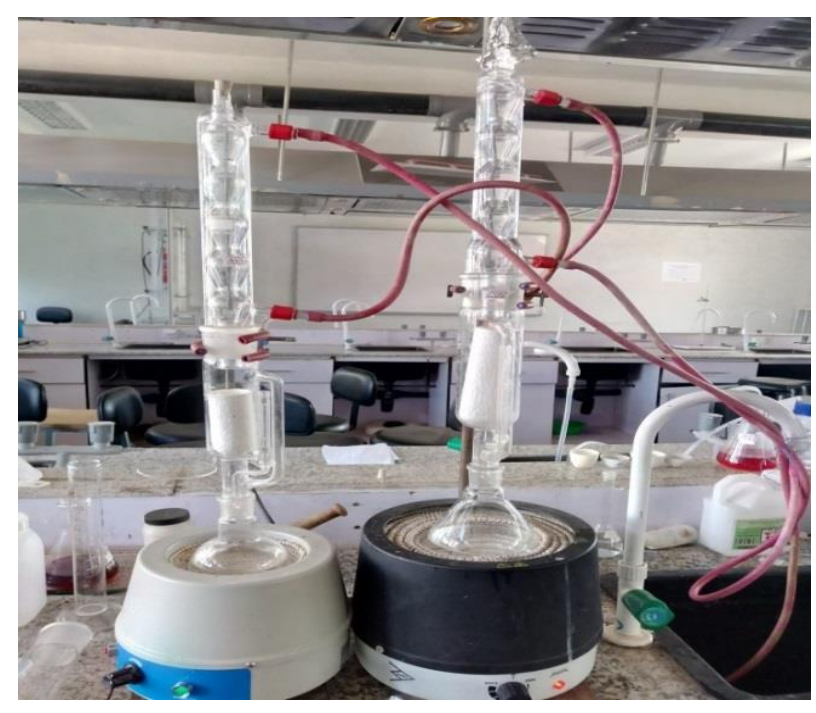

(a)

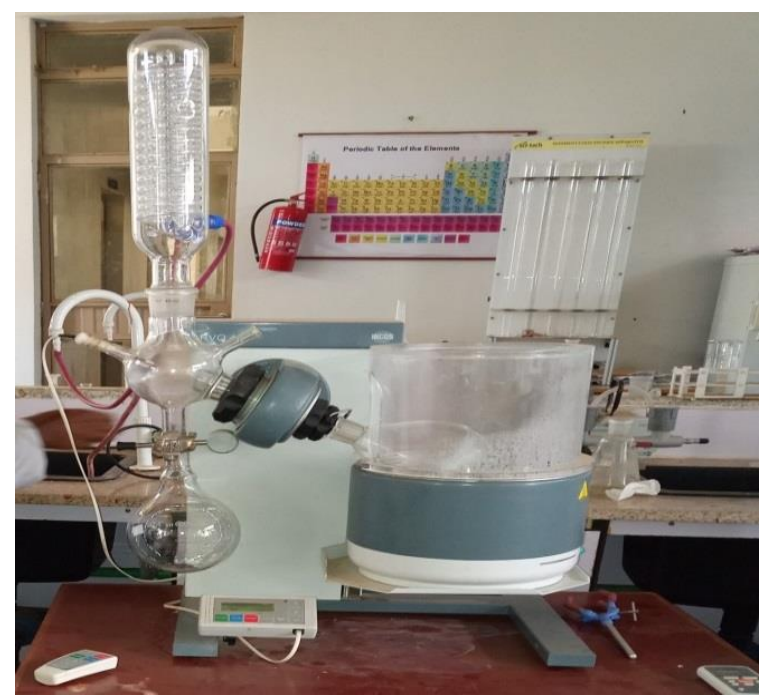

(b) 
Figures
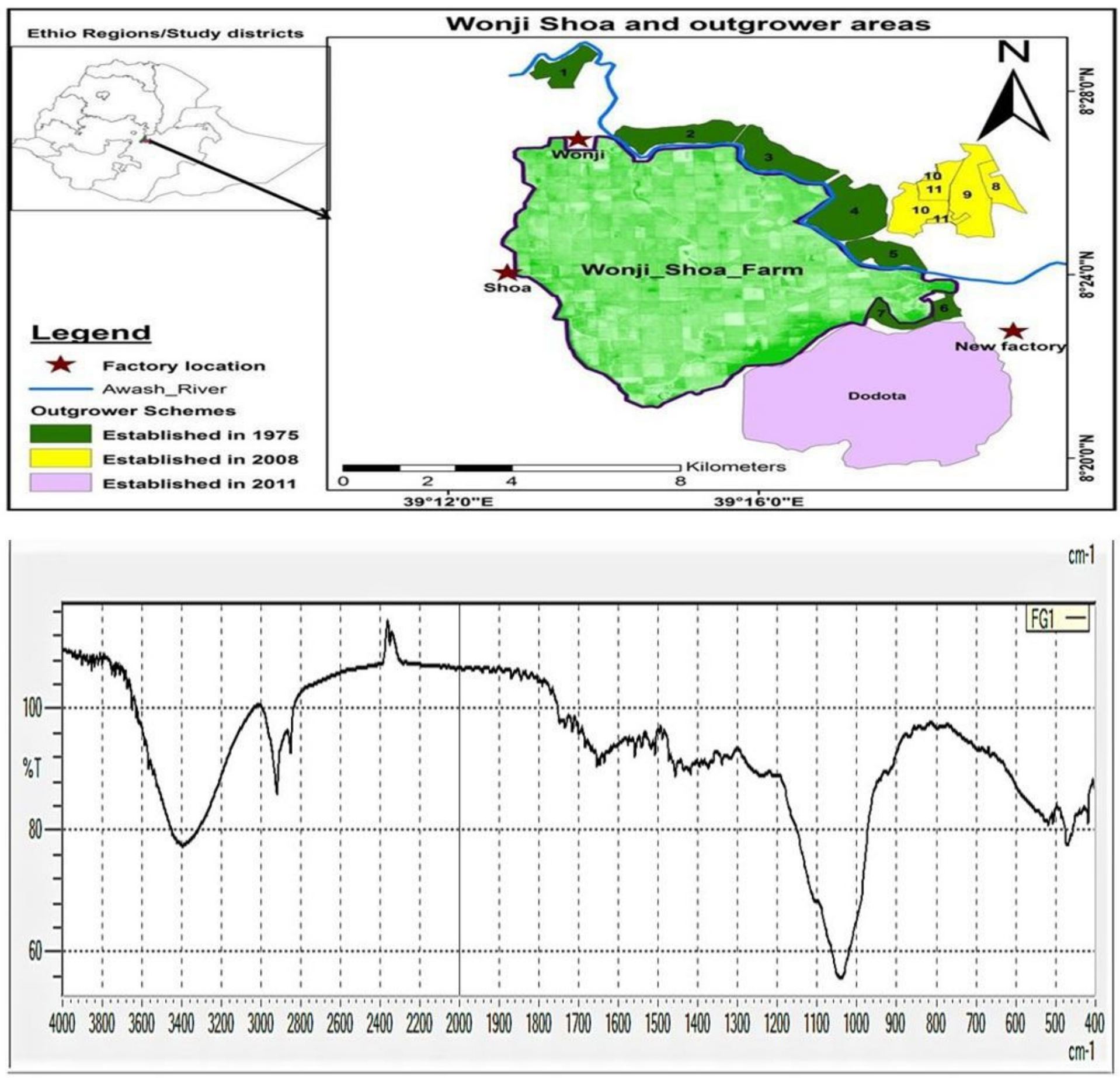

Figure 1

Location and topographic map of the study area [https://www.researchgate.net/figure/Map-of-WonjiShoa-sugar-factories] FTIR spectrum of filter cake. The spectrum of FTIR shows a broadband between 3250-3500 cm-1 which indicates the presence of both free and hydrogen-bonded $\mathrm{OH}$ groups. The stretching appeared at $2918 \mathrm{~cm}-1$ indicates the aldehyde $(\mathrm{CHO})$ group on the surface (Moshfekus et al, 2012). The stretching of $\mathrm{OH}$ groups bonded to methyl shows a signal between $2849 \mathrm{~cm}-1$ and $2916.5 \mathrm{~cm}$ - 
1 , which can represent the tetrahedral carbon of an alkane that could be attributed to the long-chain fatty acid/different amino acids of protein of the feed. Similarly, the signal at $1685 \mathrm{~cm}-1$, could represent the $\mathrm{C}=\mathrm{O}$, groups stretching of acid/ester; this may indicate the availability of fat or fatty acid in the studied feed stocks raw material filter cake. The IR spectra of the presently studied samples show a weak and broad peak at about $1645.5 \mathrm{~cm}-1$, which corresponds to the (-C-N) group, which can represent an amide group containing feed ingredient, and the peak appeared at $1456.3 \mathrm{~cm}-1$ is indicative of $-\mathrm{CH} 3$ group. The $\%$ transmittance has appeared at $1039.7 \mathrm{~cm}-1$ and it shows the presence of aliphatic amines and the broad band stretching between the ranges of 1200-900 cm-1, indicates the presence of inorganic compounds, which could be SiO42-. This is supported by Moshfekus et al, (2012), who stated that the results of IR spectrum are quite helpful in the identification of various forms of minerals present in the samples. The presently studied IR spectrums of the sample do not show any constructive signals at 2130 $\mathrm{cm}-1$ \& $1650 \mathrm{~cm}-1$ corresponding to free water molecules. It reveals that the dried filter cake is considerably free from moisture.

\section{Supplementary Files}

This is a list of supplementary files associated with this preprint. Click to download.

- APPENDICES.docx

- APPENDICES.pdf 